\title{
Vaccination Policy of the Faculty of Physicians and Surgeons of Glasgow, 1801 to 1863
}

\author{
FIONA A MACDONALD*
}

\section{Introduction}

In The modern rise of population (1976), Thomas McKeown questioned the efficacy of medical intervention and public health measures in reducing mortality. Instead, he attributed the nineteenth-century decline in mortality from infectious disease mainly to improved nutrition and a rising standard of living, both of which increased general immunity to disease. He acknowledged that public health measures had a small part to play in improving mortality in children mainly by providing clean water and effective sewerage disposal, but that these were generally effected after a downward trend in mortality had already been established. Changes in the virulence of infectious disease were largely discounted. Few studies of the decline in infectious diseases in the nineteenth century have since been completed without some reference to McKeown's analysis. ${ }^{1}$ His work inevitably led a number of historians ${ }^{2}$ to defend the implementation of public health reform as a progressive measure.

In Scotland, Glasgow achieved notoriety in Edwin Chadwick's Report on the sanitary condition of the labouring population of Great Britain (1842), but the Scottish public health movement evolved in a different fashion from the one which Chadwick championed in England. ${ }^{3}$ The challenges of the Scottish urban-industrial environment ${ }^{4}$

*F A Macdonald, MA, PhD, Wellcome Unit for the History of Medicine, University of Glasgow, 5 University Gardens, Glasgow G12 8QQ.

I should like to thank the Royal College of Physicians and Surgeons of Glasgow and the Wellcome Trust who funded this research through the Wellcome Unit in Glasgow. I am also grateful to Deborah Brunton, who was helpful in many ways, and to Johanna Geyer-Kordesch, Malcolm Nicolson, Marguerite Dupree, John Dempster and Irene Maver for their comments on an earlier draft of this paper.

${ }^{1} \mathrm{~T}$ McKeown, The modern rise of population, London, Edward Arnold, 1976. I have benefited from discussion with Malcolm Nicolson on this subject.

\footnotetext{
${ }^{2}$ For some of whom, see below p. 294 , notes 22 and 23.

${ }^{3}$ E Chadwick, Report on the sanitary condition of the labouring population of Great Britain, 1842, ed. M W Flinn, Edinburgh University Press, 1965, p. 99. "It might admit of dispute, but, on the whole, it
}

appeared to us that both the structural arrangements and the condition of the population in Glasgow was the worst of any we had seen in any part of Great Britain". Flinn's introduction gives due consideration to the Scottish public health reform movement.

${ }^{4}$ For a recent account see T M Devine, 'The urban crisis', in T M Devine and G Jackson (eds), Glasgow, vol. I: Beginnings to 1830, Manchester University Press, 1995. The problems of poverty and unemployment in nineteenth-century Scotland are discussed in $\mathrm{J} \mathrm{H}$ Treble, Urban poverty in Britain 1830-1914, London, B T Batsford, 1979. The most notorious Glasgow slum is considered in J G Robb, 'Suburb and slum in Gorbals: social and residential change 1800-1900', in G Gordon and Brian Dicks (eds), Scottish urban history, Aberdeen University Press, 1983. The problems caused by the lack of regulation in urban building during this period are revealed in $\mathbf{R}$ Rodger, 'The Victorian building industry and the housing of the Scottish working class', in M Doughty (ed.), Building the industrial city, Leicester University Press, 1986. 


\section{Fiona A Macdonald}

elicited a variety of responses-municipal sanitary, medical, evangelical, philanthropic, voluntary poor relief-which jointly (in the absence of a public health Act until 1867) formulated early public health policy in Scotland. ${ }^{5}$ Aspects of municipal sanitary administration such as cleansing were covered by the early Scottish Police Acts (Glasgow's was passed in 1800), an area where Brenda White has demonstrated that medical involvement was through the network of Police Surgeons. ${ }^{6}$ A system of District Surgeons also operated under the poor law, ${ }^{7}$ while ad hoc Boards of Health were set up by the magistrates in the 1830 s and 1840 s to deal with typhus and cholera epidemics. 8 "A byword for urban squalor", 9 Glasgow provided ample opportunity for the sanitary and hygiene reform which, as south of the border, was the earliest manifestation of the movement. Here, Ian Adams has emphasized the importance of burgh reform (1833-4) in establishing a structure in which local sanitary initiatives could develop. ${ }^{10}$ Glasgow's first Inspector of Cleansing was appointed, under a fairly broad remit, in $1843,{ }^{11}$ and sanitary inspectors under the auspices of the Nuisance Removal Act (Scotland) 1856, ${ }^{12}$ but supreme amongst early reform was the development of the Loch Katrine Water-works (1854-62) which brought clean water to the city. ${ }^{13}$

Accompanying criticism of the inadequacy of poor relief provision to combat the problems of the industrial environment led to various means of aiding the urban destitute. A spate of literature has evaluated the social reform theories of the evangelical minister Thomas Chalmers, who attempted (relatively unsuccessfully) to implement voluntary

\footnotetext{
${ }^{5}$ Early public health initiatives in Scotland are discussed in J H F Brotherston, Observations on the early public health movement in Scotland, London, H K Lewis, 1952, and from a Glasgow perspective in A K Chalmers, The health of Glasgow 1818-1925, Glasgow Corporation, 1930. However, both these works are now dated. A comprehensive overview of general social and welfare policy can be found in T Ferguson, The dawn of Scottish social welfare: a survey from medieval times to 1863 , London and Edinburgh, Thomas Nelson, 1948. A second volume looks at the later period, idem, Scottish social welfare 1864-1914, London and Edinburgh, E \& S Livingstone, 1958.

${ }^{6} \mathrm{~B}$ White, 'Medical police. Politics and police: the fate of John Roberton', Med. Hist., 1983, 27 : 407-22; idem, 'Training medical policemen: forensic medicine and public health in nineteenthcentury Scotland', in M Clark and C Crawford (eds), Legal medicine in history, Cambridge University Press, 1994.

${ }^{7} \mathrm{O}$ Checkland, 'Chalmers and William Pulteney Alison: a conflict of views on Scottish social policy', in A C Cheyne, The practical and the pious, Edinburgh, Saint Andrew Press, 1995, pp. 132, 138. There were four District Surgeons in 1816 and twelve by 1831 . These positions had been historically filled by the Faculty of Physicians and Surgeons of Glasgow.

8 J B Russell, Public health administration in Glasgow, ed. A K Chalmers, Glasgow, MacLehose,
}

1905, pp. 16-17; D Hamilton, The healers: a history of medicine in Scotland, Edinburgh, Canongate, 1981, pp. 186-7.

${ }^{9} \mathrm{R}$ H Campbell, 'The making of the industrial city', in Devine and Jackson (eds), op. cit., note 4 above, p. 185. Some of the earliest photographs of Glasgow can be seen in J F McCaffrey (ed.), Shadow's midnight scenes and social photographs: Glasgow 1858, University of Glasgow Press, 1976, facsimile reprint.

${ }^{10}$ I A Adams, The making of urban Scotland, London and Montreal, Croom Helm, 1978, pp. 127-54. For a schematic comparison of the development of public health legislation in England and Scotland, refer to p. 139.

${ }^{11}$ Russell, op. cit., note 8 above, p. 15 . For a schematic chronology of the development of sanitary and health administration, see Russell, pp. 3 (1800-1854), 19 (1855-1864), 22 (1865-1874).

${ }^{12}$ White, 'Training medical policemen', op. cit., note 6 above, p. 156.

${ }^{13}$ The classic account remains J D Marwick's Glasgow: the water supply of the city, Glasgow, Robert Anderson, 1901, but this subject is briefly reassessed in W H Fraser and I Maver (eds), Glasgow, vol. II: 1830 to 1912, Manchester University Press, 1996, ch. 11. I am grateful to Irene Maver for kindly allowing me to see two chapters of this book prior to publication. For a contemporary account see J Burnet, History of the water supply of Glasgow, Glasgow, s.n., 1869. 


\section{Vaccination Policy of the FPSG}

relief measures in Glasgow's Tron parish in the early $1820 \mathrm{~s} .{ }^{14}$ The cult of respectability attending the growth of evangelicalism seems also to have increased the fear of venereal disease, resulting in the opening of Glasgow Lock Hospital in 1805 and the Magdalene hospital (where women transferred once free of disease) in $1815 .{ }^{15}$ A similar dynamic was at work in the temperance movement. ${ }^{16}$ Philanthropy and voluntarism-areas elucidated by Olive Checkland ${ }^{17}$-provided additional health care and social welfare in Scottish cities, but ultimately the failure to cope with the urban destitute and able-bodied unemployed led to the promulgation of a new Scottish Poor Law in $1845 .{ }^{18}$ There was, none the less, a time lapse in early nineteenth-century Scottish public health action which has been variously blamed on the middle-class preoccupation with destitution, the diversionary aspects of the 1843 Disruption of the Kirk, the abhorrence of secular sanitary intervention by religious groups constrained by the doctrine of predestination, municipal parsimony, ignorance of the Scottish legal system, and the failure of the medical

\footnotetext{
${ }^{14}$ See R Cage and O Checkland, 'Thomas Chalmers and urban poverty: the St. John's parish experiment in Glasgow, 1819-1837', Glasgow philos. J., 1976, 13: 37-56; J F McCaffrey, 'Thomas Chalmers and social change', Scott. hist. Rev., 1981, 40 pt. 1: 32-60; S J Brown, 'Glasgow and the urban challenge', in idem, Thomas Chalmers and the Godly commonwealth in Scotland, Oxford University Press, 1982; Checkland, op. cit., note 7 above; $\mathrm{S} J$ Brown, 'Thomas Chalmers and the communal ideal in Victorian Scotland', Proc. Brit. Acad., 1992, 78: 61-80.

${ }^{15}$ T C Smout, 'Aspects of sexual behaviour in nineteenth century Scotland', in A A MacLaren (ed.), Social class in Scotland, Edinburgh, John Donald, 1976, p. 57; O Checkland, Philanthropy in Victorian Scotland, Edinburgh, John Donald, 1980, pp. 194, 235-8. The role of the evangelical spirit in the control of venereal disease is discussed in ch. 12 in K M Boyd, Scottish church attitudes to sex, marriage and the family, 1850-1914, Edinburgh, John Donald, 1980, pp. 186-98.

${ }^{16}$ Hamilton, op. cit., note 8, pp. 218-20; Fraser and Maver (eds.), op. cit., note 13 above, ch. 11, section 3. For a detailed study of the temperance movement see D Paton, 'Drink and the temperance movement in Scotland in the nineteenth century', $\mathrm{PhD}$ dissertation, University of Edinburgh, 1976. I owe this reference to Irene Maver. For a survey of adulteration in the drink industry in mid-nineteenthcentury Glasgow (in which druggists played a part), see E Burns, It's a bad thing whisky, especially bad whisky, Glasgow, Balvag Books, 1995.

${ }^{17}$ Checkland, op. cit., note 15 above; $O$ Checkland and M Lamb (eds), Health care as social history: the Glasgow case, Aberdeen University Press, 1982.
}

\begin{abstract}
${ }^{18}$ Major historical reassessment on the Scottish Poor Law has been done by R Cage. See R A Cage, The Scottish Poor Law 1745-1845, Edinburgh, Scottish Academic Press, 1981; see also A Paterson, 'The Poor Law in nineteenth-century Scotland', in D Fraser (ed.), The new Poor Law in the nineteenth century, London and Basingstoke, Macmillan, 1976; and for an account of the administrative changes introduced by the new law, D E Gladstone, 'The new Poor Law in Scotland: the administrative reorganisation of the first quinquennium', Soc. econ. Admin., 1975, 9: 115-27. The specifics of the debate surrounding the Poor Law in Glasgow are discussed in S Nenadic, 'The Scottish Poor Law debate: Glasgow in the 1840s', BA thesis, University of Strathclyde, 1981. I am grateful to Irene Maver for this reference. The operation of the new Poor Law in the Glasgow context has been looked at by Stephanie Blackden and Carolyn Pennington, while the modus operandi of the Board of Supervision-the administrative body (with some public health responsibilities) established by the new law-has been considered by Ian Levitt. $S$ Blackden, 'The Poor Law and health: a survey of parochial medical aid in Glasgow, 1845-1900', in T C Smout (ed.), The search for wealth and stability, London and Basingstoke, Macmillan, 1979; idem, 'The development of public health administration in Glasgow 1842-1872', PhD thesis, University of Edinburgh, 1976; C I Pennington, 'Mortality, public health and medical improvements in Glasgow 1855-1911', PhD thesis, University of Stirling, 1977; idem, 'Mortality and medical care in nineteenth-century Glasgow', Med. Hist., 1979, 23: 442-50; I Levitt, Government and social conditions in Scotland 1845-1919, Edinburgh, Scottish History Society, 1988.
\end{abstract}




\section{Fiona A Macdonald}

profession to be in the vanguard of sanitary reform. ${ }^{19}$ Probably nearer to the truth was the Scottish medical profession's unwillingness to submit itself to the vagaries of centralist "non-medical bureaucratic bodies". 20

Although McKeown made an exception for vaccination against smallpox, he implied, none the less, that immunization played only a small part in reducing mortality, implicitly questioning the value of early nineteenth-century vaccination campaigns against smallpox. ${ }^{21}$ His thesis has, consequently, undergone substantial modification by a number of scholars. A J Mercer posited that the basis for mortality decline was preventive and public health measures because major epidemic diseases such as smallpox could not have receded so significantly by the end of the nineteenth century without preventive action. ${ }^{22}$ Similarly, Simon Szreter argued that human agency, in the form of local administered sanitary measures and the public health movement, did most to reduce mortality levels. ${ }^{23}$ Most recently, Anne Hardy's examination of infectious diseases in the late nineteenth century placed greater emphasis on autonomous changes in the virus itself and the importance of developing a range of supplementary preventive techniques which potentiated vaccination's effect in reducing mortality. ${ }^{24}$

R A Houston's reassessment of the patterns in Scottish demography concurs with English studies in showing a downward mortality trend between $c$. 1750 and 1860, but indicates that this was less to do with a rise in fertility than to improvements in life expectancy. ${ }^{25}$ Within this, Rory Williams highlights an upward turn in the death rate in Glasgow between 1831 and 1871 due to poverty, overcrowding, and inadequate diet, exacerbated by a period of heavy immigration from Ireland and the Highlands. However, he discounts as significant factors in Glasgow's mortality crisis the alleged importation of insanitary living conditions and the development of insufficient immunity to urban diseases by the Celts. Economic and medical factors were more important. ${ }^{26}$ In addition, specific studies of smallpox in Scotland by Deborah Brunton have revealed the strong antipathy to inoculation in the western Lowlands which was "too little practised to have

\footnotetext{
${ }^{19}$ A A MacLaren, 'Bourgeois ideology and Victorian philanthropy: the contradictions of cholera', in MacLaren (ed.), op. cit., note 15 above, pp. 41-2; Flinn's introduction to Chadwick's Report, op. cit., note 3 above, p. 8; Hamilton, op. cit., note 8 above, p. 202. Among presbyterians, the greatest objections manifested in the Seceder churches, but emerged to some extent in Congregationalists, Methodists and Baptists.

${ }^{20}$ Flinn's introduction to Chadwick's Report, op. cit., note 3 above, p. 72 .

${ }^{21} \mathrm{McKeown}$, op. cit., note 1 above, pp. 107-9, 113.

${ }^{22}$ A J Mercer, 'Smallpox and epidemiologicaldemographic change in Europe: the role of vaccination, Popul. Stud., 1985, 39: 287-307, pp. 293-4; idem, Disease, mortality and population in transition, Leicester University Press, 1990.

${ }^{23}$ Simon Szreter, 'The importance of social intervention in Britain's mortality decline c.1850-1914: a re-interpretation of the role of public
}

health', Soc. Hist. Med., 1988, 1: 1-37.

${ }^{24}$ A Hardy, The epidemic streets: infectious disease and the rise of preventive medicine, 1856-1900, Oxford, Clarendon Press, 1993, pp. 1-3, 111-12, 124, 292-3; idem, 'Smallpox in London: factors in the decline of the disease in the nineteenth century', Med. Hist., 1983, 27: 111-38.

${ }^{25} \mathrm{R}$ A Houston, 'The demographic regime', in T $\mathrm{M}$ Devine and R Mitchison (eds), People and society in Scotland, I, 1760-1830, Edinburgh, John Donald in association with the Economic and Social History Society of Scotland, 1988, pp. 17, 23-4.

${ }^{26} \mathrm{R}$ Williams, 'Medical, economic and population factors in areas of high mortality: the case of Glasgow', Sociol. Health Illn., 1994, 16(2): 143-81, pp. 170-2. Irish and Scots are also jointly considered in W Sloan, 'Aspects of the assimilation of Highland and Irish migrants in Glasgow, 1830-1870', PhD thesis, University of Strathclyde, 1987. 


\section{Vaccination Policy of the FPSG}

more than a minimal effect on mortality", ${ }^{27}$ and the strength of the Scottish Royal Colleges in shaping the Scottish Vaccination Act, after a series of smallpox epidemics revealed the inadequacy of the voluntary vaccination system in controlling the disease. ${ }^{28}$ However, the main overview of public vaccination in Scotland, in M W Flinn's Scottish population history (1977), states that the widespread adoption of vaccination in the first few years of the nineteenth century (which had "the most dramatic effect" in Glasgow) was responsible for an immediate and substantial reduction in smallpox mortality. Flinn concluded that, after its initial successes had reduced fear of the disease, vaccination lost some of its early attraction, which led to a moderate rise in mortality in the late $1830 \mathrm{s.}^{29}$ Before the Vaccination Act, it was the early adoption of voluntary vaccination by the Royal College of Surgeons in Edinburgh and the Faculty of Physicians and Surgeons in Glasgow (hereafter FPSG or the Faculty), with the assistance of the Kirk, which led to a significant decline in smallpox mortality in Scotland. ${ }^{30}$

This paper is a case-study of early voluntary vaccination in Scotland from the minutes and vaccination registers of the FPSG. It covers the period from the start of their vaccination campaign in 1801 to the passing of the 1863 Vaccination Act, and considers this debate in the context of the FPSG's experience of vaccination practice. Although the Faculty vaccinated some 24,000 children free of charge in the first two decades of the century, there is little to indicate a sustained corporate interest in public health during this period. Some Faculty members certainly became key individuals in the sanitary reform movement in Glasgow, ${ }^{31}$ but the town council was the driving force here, and public health was mainly, if not entirely, a phenomenon of the late nineteenth century. The Faculty's encouragement of public health education is the only other enduring aspect of the corporation's involvement with preventive medicine in the early nineteenth century. What it did practically, as a body, to alleviate the ravages of smallpox therefore assumes much greater significance.

\section{I}

\section{The Faculty Vaccination Programme 1801-1820}

In Glasgow, a growing, urban conurbation with all the social and public health problems associated with industrial expansion, smallpox was endemic. ${ }^{32}$ Indeed, towards the end of the eighteenth century, smallpox in Glasgow "appears to have been more mortal to children than anywhere else in Britain". ${ }^{33}$ It was this age group which the Faculty's vaccination programme between 1801 and 1863 particularly targeted.

\footnotetext{
${ }^{27} \mathrm{D}$ Brunton, 'Smallpox inoculation and demographic trends in eighteenth-century Scotland', Med. Hist., 1992, 36: 403-29, p. 406.

${ }^{28}$ Idem, 'Practitioners versus legislators: the shaping of the Scottish Vaccination Act', Proc. $R$. Coll. Physicians Edinb., 1993, 23: 193-201, p. 195.

${ }_{29}$ M W Flinn (ed.), Scottish population history from the 17th century to the 1930s, Cambridge University Press, 1977, pp. 393-5.

${ }^{30}$ Houston, op. cit., note 25 above, pp. 15-16.

${ }^{31}$ For instance, Robert Cowan, Professor of Medical Jurisprudence at the University of Glasgow,
} 


\section{Fiona A Macdonald}

With powers (which extended up to the Medical Act of 1858) to examine and regulate medical practice in Glasgow and the west of Scotland, the FPSG was an independent medical corporation established by a Royal Charter of James VI in $1599 .{ }^{34}$ In April 1801, it had a membership of 41 , as well as 50 country licentiates. ${ }^{35}$ Its members formed an integral part of the Glasgow medical educational establishment together with the Glasgow Royal Infirmary, the University Medical Faculty, Anderson's Institution ${ }^{36}$ and a number of medical societies of which the Glasgow Medical Society was the premier. ${ }^{37}$ Just prior to the implementation of its vaccination campaign, the Faculty entered a period of corporate rejuvenation after moving to a new hall in 1791. The President and three FPSG members were also nominees to the board of managers of the Glasgow Royal Infirmarythe first clinical teaching hospital of any significance in the city-which opened in 1794 in response to the growing health problems of industrialization. ${ }^{38}$ They controlled clinical appointments there for almost a century. ${ }^{39}$ The Faculty's assumption of a role in the prevention of smallpox in the city can therefore be viewed as the extension of their corporate rejuvenation into the realm of public health.

There were precedents for the FPSG's vaccination programme in both its own, and the Edinburgh Royal College of Physicians' provision of medical care to the poor, ${ }^{40}$ particularly their promotion of inoculation. Though never as extensive as in England, inoculation campaigns in Scotland were a similar manifestation of the medical profession's interest in the voluntarist and humanitarian initiatives preceding the public health movement of the mid-nineteenth century. ${ }^{41}$ In Glasgow, Dr John Gordon and his erstwhile apprentice, Dr John Moore, inoculated 651 people between 1752 and 1756, only one of whom died. ${ }^{42}$ However, the incentive for supporting a public service seems to have

\footnotetext{
34 The bounds of its jurisdiction were defined under its charter as the baronies of Glasgow, Renfrew and Dumbarton, and the sheriffdoms of Clydesdale, Renfrew, Lanark, Kyle, Carrick, Ayr and Cunningham. Faculty of Physicians and Surgeons of Glasgow, The Royal Charter and Laws of the Faculty of Physicians and Surgeons of Glasgow, Glasgow, s.n., 1821, p. 6.

${ }^{35}$ Royal college of Physicians and Surgeons of Glasgow (hereafter RCPSG) $1 / 1 / 1 / 3$, Minutes of the FPSG, 1757 to 1785 , p. 349 ; RCPSG $1 / 1 / 1 / 4$, Minutes of the FPSG, 1785 to 1807 , fols. $1 \mathrm{r}$ to $167 \mathrm{v}$.

${ }^{36}$ For more on this institution, see below p. 297.

${ }^{37}$ For an overview of medical societies in Scotland see J Jenkinson, Scottish medical societies 1731-1939, Edinburgh University Press, 1993; idem, 'The role of medical societies in the rise of the Scottish medical profession, 1730-1939', Soc. Hist. Med., 1991, 4: 253-76.

${ }^{38}$ Alexander Duncan, Memorials of the Faculty of Physicians and Surgeons of Glasgow, 1599-1850, Glasgow, James MacLehose, 1896, p. 108. The role of the Infirmary in the care of the sick poor is discussed in M W Dupree, 'Family care and hospital care: the "sick poor" in nineteenth-century
}

\author{
Glasgow', Soc. Hist. Med., 1993, 6 pt 2: 195-211. \\ ${ }^{39} \mathrm{~J}$ Jenkinson, M Moss and I Russell, The Royal: \\ the history of the Glasgow Royal Infirmary \\ 1794-1994, Glasgow, Bicentenary Committee on \\ behalf of Glasgow Royal Infirmary NHS Trust, \\ 1994, pp. 23-4, 39-42, 48. \\ ${ }^{40}$ Checkland, op. cit., note 15 above, p. 202. \\ ${ }^{41} \mathrm{C}$ Hamlin, 'State medicine in Great Britain', in \\ D Porter (ed.), The history of public health and the \\ modern state, Amsterdam and Atlanta, Rodopi, \\ 1994, pp. 134-5. For a perceptive article which \\ argues the continuity between these earlier \\ voluntary, and the later statutory, measures in \\ Scotland and Ireland as well as England and Wales, \\ see J V Pickstone, 'Dearth, dirt and fever epidemics: \\ rewriting the history of British "public health", \\ 1780-1850', in T Ranger and P Slack (eds), \\ Epidemics and ideas, Cambridge University Press, \\ 1992. \\ ${ }^{42} \mathrm{H}$ L Fulton, 'John Moore, the medical \\ profession and the Glasgow enlightenment', in A \\ Hook and R B Sher (eds), The Glasgow \\ enlightenment, East Linton, Tuckwell Press, 1995, p. \\ 181.
}




\section{Vaccination Policy of the FPSG}

come from the Royal College of Surgeons and the Royal College of Physicians in Edinburgh who, in the 1780s and 1790s, offered free inoculation to "the Children of the lower ranks". 43

Whereas inoculation induced immunity by infecting the recipient with matter containing live smallpox virus, vaccination immunized against smallpox by infection with cowpox, a harmless disease of cows. ${ }^{44}$ Although vaccination appears to have been in use in the last few decades of the eighteenth century, Jenner's work was none the less influential in persuading the medical profession to appreciate its effectiveness. ${ }^{45}$ By 1800 , some FPSG members were sufficiently convinced of its safety through their own experimentation, that they wished to share its benefits with the poor of the city.

The Faculty's decision to establish a vaccine institution in Glasgow was based on "the ascertained value" of an earlier station set up by two Faculty members in 1799. ${ }^{46}$ This date indicates how exceptionally early Jenner's vaccination procedure was implemented in Glasgow. ${ }^{47}$ The first official vaccination with cowpox in the city was performed on 30 May 1799, by the surgeon William Nimmo, ${ }^{48}$ on a child of Dr Thomas Garnett. ${ }^{49}$ A former pupil of John Brown in Edinburgh, ${ }^{50}$ Garnett was the Professor of Natural Science at the newly established Anderson's Institution, ${ }^{51}$ the first Glasgow college to teach a medical curriculum outside the University. ${ }^{52}$ He became a member of the FPSG in $1798,{ }^{53}$ and as someone of recognized medical status, Garnett's willingness to submit his own offspring to vaccination was a valuable advertisement. By the 1830 s, the medical professors at Anderson's, whose teaching and class certificates were recognized by the FPSG, were nearly all Faculty members. ${ }^{54}$

\footnotetext{
${ }^{43}$ W S Craig, History of the Royal College of Physicians of Edinburgh, Oxford, Blackwell Scientific Publications, 1976, p. 181; C H Creswell, The Royal College of Surgeons of Edinburgh, Edinburgh, Oliver and Boyd, 1926, p. 165.

${ }^{44}$ W F Bynum, E J Browne, R Porter (eds), Dictionary of the history of science, Princeton University Press, 1985, p. 207.

${ }^{45}$ Mercer, Disease, mortality and population, op. cit., note 22 above, p. 48 .

${ }^{46}$ Chalmers, op. cit., note 5 above, p. $351 \mathrm{fn}$.

${ }^{47}$ His connection with the Hunters who came from East Kilbride may have encouraged this. See J L Turk, E Allen, 'The influence of John Hunter's inoculation practice on Edward Jenner's discovery of vaccination against smallpox', J. R. Soc. Med., 1990, 83: 266-7, who mention that Jenner was aware of the prophylatic power of cowpox while still a pupil of Hunter.

${ }^{48}$ It seems likely that Nimmo was a founder of the experimental station. Nimmo entered the Faculty in 1785 . He worked with his brother and partner, Alexander Nimmo, who entered two years after him. Duncan, op. cit., note 38 above, pp. 263-4.

${ }^{49}$ For more on Garnett see S G E Lythe, Thomas Garnett (1766-1802): Highland tourist, scientist and professor, medical doctor, Glasgow, Polpress, 1984.
}

\author{
${ }^{50}$ D C McVail, 'On Anderson's College; its \\ founder and its medical school, being the \\ introductory address at the commencement of the \\ session 1878-79', Glasgow med. J., 3rd s., 1879, 11: \\ 99-117, p. 107. For John Brown's theory and \\ system of medicine see W F Bynum and R Porter \\ (eds), Brunonianism in Britain and Europe, London, \\ Wellcome Institute for the History of Medicine, \\ 1988; G B Risse, 'The Brownian system of \\ medicine: its theoretical and practical implications', \\ Clio Medica, 1970, 5: 45-51. \\ ${ }^{51}$ Duncan, op. cit., note 38 above, pp. 153 fn. 1 , \\ 180, 267. \\ ${ }^{52}$ For Anderson's College Medical School see A \\ Humboldt Sexton, The first technical college: $a$ \\ sketch of the history of "The Andersonian," and the \\ Institutions descended from it 1796-1894, London, \\ Chapman and Hall, 1894, pp. 154-63; J Butt, John \\ Anderson's legacy: the University of Strathclyde and \\ its antecedents 1796-1996, East Linton, Tuckwell \\ Press, 1996, chs 1-4. \\ ${ }^{53}$ RCPSG 1/1/1/4, fol. 141r. 1 January 1798. \\ ${ }^{54}$ Butt, op. cit., note 52 above, p. 49 . A pamphlet \\ of $c .1860$ entitled 'Medical School, Anderson's \\ University, Glasgow' gives the names of the ten \\ lecturers teaching subjects in the medical \\ curriculum. All but one were members of the \\ Faculty. RCPSG, Glasgow Collection, Pamphlets \\ Glasgow 11.
}




\section{Fiona A Macdonald}

The Faculty's purpose in establishing a programme of vaccination was to provide a place for the public to be vaccinated, and to popularize the procedure by advertising widely. ${ }^{55}$ In the first quarter of the century, the rate of public vaccination in Glasgow, undertaken mainly by the Faculty, was matched in only two other British cities, Newcastle and Manchester. ${ }^{56}$ Vaccination was thought to be a significant factor in the population growth recorded in the 1811 census, ${ }^{57}$ a conclusion supported by the publication of $\mathrm{Dr}$ Robert Watt's mortality statistics for Glasgow, which showed that the percentage mortality from smallpox in the under-tens had fallen from 19 per cent in the period 1783 to 1800 to 6 per cent between 1801 and 1812. ${ }^{58}$ Watt (an FPSG member) went as far as to attribute the dramatic reduction in the number of smallpox deaths by 1812 entirely to the Faculty's vaccination of infants free of charge. ${ }^{59}$

The FPSG's campaign against smallpox was launched on 6 May 1801 when a committee appointed to draw up an advertisement in favour of cowpox inoculation 60 intimated the following:

The Faculty of Physicians and Surgeons in Glasgow being of opinion that much benefit might be derived from a more extensive Inoculation for the Cow pox, as well as a more general substitution of that disorder for the Common inoculated small pox, than have hitherto prevailed in this City and neighbourhood, surely inform the public that two of their number are appointed to attend every monday ${ }^{61}$ betuixt 12 and 1 oclock $^{62}$ at their Hall St Enoch's Square on purpose to Inoculate gratis, with Cow pox matter, such Children or others as may be deemed fit subjects for the operation. ${ }^{63}$

Henceforth, two members attended the Hall ${ }^{64}$ every Monday, between 12 and 1 o'clock, ${ }^{65}$ and a third member was appointed as recorder. ${ }^{66}$ The contents of the vaccination registers, thus compiled, and the decisions of special committees on vaccination recorded in the minutes, provide a detailed record of the progress of the Faculty's vaccination programme between 1801 and $1896 .^{67}$

${ }^{55}$ Duncan, op. cit., note 38 above, pp. 137-9.

${ }^{56}$ Creighton, op. cit., note 33, vol. 2, p. 584.

${ }^{57}$ Flinn (ed.), op. cit., note 29 above, p. 392.

${ }^{58}$ Brunton, op. cit., note 27 above, p. 425; Robert

Watt, Treatise on the history, nature, and treatment of chincough: ... Appendix. An inquiry into the relative mortality of the principal diseases of children, Glasgow, John Smith, 1813, pp. 343-60, 361-72.

${ }^{59} \mathrm{G}$ McLachlan (ed.), Improving the common weal: aspects of Scottish health services 1900-1984, Edinburgh University Press, 1987, p. 549.

${ }^{60}$ This comprised the President Dr Millar, Dr Wright, Mr Scruton, Dr Brown, Mr Cooper and $\mathrm{Mr}$ Nimmo, appointed on 6 April. RCPSG 1/1/1/4, fol. 168r. Modern pencil foliation in use, at foot of page.

${ }^{61}$ Monday had been the day appointed for seeing the poor in the 1599 Charter. Attending to the poor in need of vaccination seems to have been a historical continuation of this. RCPSG $1 / 1 / 1 / 1 b$, Transcript Minutes of the FPSG, 1599 to 1688 , p. 3.

${ }^{62}$ In 1820 , the day was changed to a Tuesday at 12 o'clock. By 1850 , it had reverted to Monday at 12 o'clock. RCPSG 1/1/1/5, fol. 253 v; RCPSG
1/1/1/8, Minutes of the FPSG, 1848 to 1859 , p. 180.

${ }^{63}$ RCPSG $1 / 1 / 1 / 4$, fol. $168 \mathrm{r}$.

${ }^{64}$ On only one occasion during this period, in January 1811 , were four members appointed to vaccinate in the following month. The increase was probably because of the greater incidence of smallpox in 1811 , or was possibly in response to outside interest from the NVE, but appears to have been temporary.

65 There seems to have been some discrepancy over the time. The committee stated between 1 and 2 o'clock, but in practice, as intimated in the newspaper advertisement, the vaccinators seem to have decided on the earlier time.

${ }^{66}$ RCPSG $1 / 1 / 1 / 4$, fol. 168r. He noted the name, age and address of the vaccinee, together with how the vaccination took.

${ }^{67}$ RCPSG $1 / 7 / 1-15$, Faculty Vaccination Registers, 1801 to 1896 . The FPSG's policy on vaccination is mainly found in the minutes. The content and nature of the first eleven registers is considered fully in a second paper, as yet in typescript, which analyses the more technical aspects of vaccination. 


\section{Vaccination Policy of the FPSG}

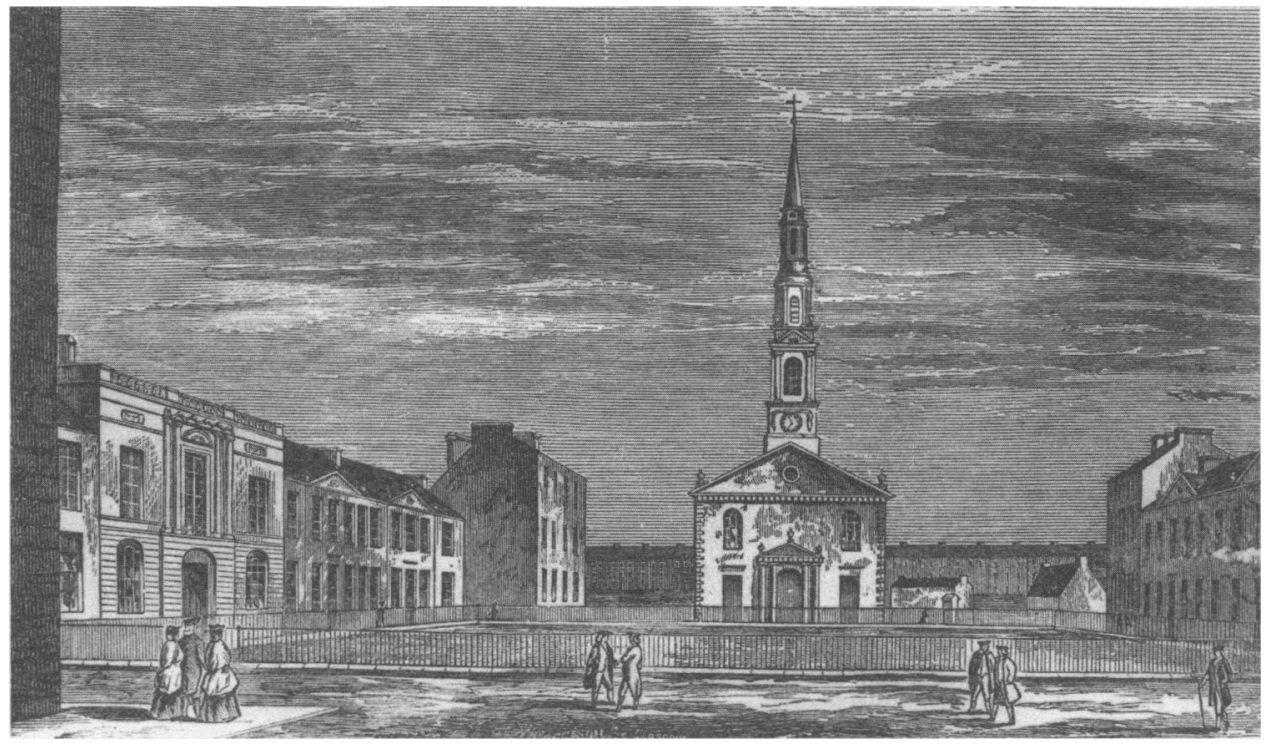

Figure 1: View of St Enoch's Square, with Surgeon's Hall (first building on the left) and church, in 1782. (Source: Various authors, The history of Glasgow, from the earliest to the present time, 2 vols, Glasgow, John Tweed, 1872, vol. 2, p. 1087.)

Of the first vaccinators, Messrs James Monteith (or Monteath) and John MacArthur, ${ }^{68}$ only the former had a prior interest in inoculation. ${ }^{69}$ The involvement of Monteith (one of the original trustees of Anderson's Institution) ${ }^{70}$ and Nimmo establishes an indisputable connection between the early Faculty vaccinators and Anderson's Institution, but their membership of the Faculty probably afforded them better opportunity to implement a public vaccination programme. Medical altruism notwithstanding, this was one way in which the Faculty could define a continuing role for itself as the number of competing medical institutions in the city grew because its charter of 1599 legally enshrined an obligation on it to benefit the health of the poor. ${ }^{71}$ Dealing with a rampant public health

${ }^{68}$ RCPSG 1/1/1/4, fol. 168v. John MacArthur entered the Faculty in 1800 and was surgeon to the Glasgow Sharp-shooters. Duncan, op. cit., note 38 above, p. 268.

${ }^{69}$ Duncan, op. cit., note 38 above, p. 134. Monteith entered the Faculty in 1777 . He was probably Nimmo's partner in the early vaccination station. Advertising a course of lectures in midwifery in the Glasgow Journal on 19 March 1778 , he stated that this would include "observations on Inoculation, \&c." Monteith offered his course after the failing health of Thomas Hamilton, Professor of Anatomy and Botany at the University of Glasgow, led to the discontinuation of his midwifery lectures and a consequent gap in the market. D A Dow, The Rottenrow: the history of the
Glasgow Royal Maternity Hospital 1834-1984, Carnforth, Parthenon Press, 1984, p. 127.

${ }^{70}$ Duncan, op. cit., note 38 above, pp. 134, 179, 261-2. He also became Professor of the Practice of Medicine there.

${ }^{71}$ The Royal Charter and Laws, op. cit., note 34 above, p. 9. The seventh clause specified: "That the said Visitors, their brethren and Successors, shall conveen every first Monday of ilk Month, at some convenient place, to visit and give counsel to poor diseased folks, gratis". Its decision of 6 December 1802 , to revert to the former practice of vaccinating for cowpox gratis at monthly meetings, should therefore be seen in this light-though there is no indication that this was actually implemented. RCPSG $1 / 1 / 1 / 4$, fol. 202r v. 


\section{Fiona A Macdonald}

problem in Scotland's largest city allowed the Faculty to fulfil this obligation and to demonstrate that it was not an anachronistic guild institution. ${ }^{72}$

Vaccination aside, it cannot be said that the FPSG showed much interest, in corporate terms, in spearheading the public health movement in early nineteenth-century Glasgow. Its main concern was always to preserve the privileges of its own jurisdiction, in particular, and the medical profession, in general. For instance, in 1818, a committee were appointed to take such action as was deemed necessary on the Passenger Vessel Act because the 7th section broached upon the Faculty's rights. This specified that ships' surgeons had to have a surgical licence from the colleges of surgeons in Edinburgh, Dublin or London, or a surgical degree from Glasgow University, but it failed to mention the FPSG. ${ }^{73}$ However FPSG members did make individual contributions to the public health campaign. Robert Cowan, Professor of Medical Jurisprudence at the University (1839-1841) - a chair founded to promote teaching in public health-was Chadwick's ally in Glasgow. ${ }^{74}$ The first police surgeons in Glasgow, with joint forensic and public health duties, were FPSG members Francis Neilson, ${ }^{75}$ James Corkindale ${ }^{76}$ and John Easton. ${ }^{77}$ The Faculty also promoted the teaching of public health by its agreement, on 4 April $1831,{ }^{78}$ that attendance at one session's lectures in medical jurisprudence be mandatory for the FPSG's surgical diploma. ${ }^{79}$

The first Faculty vaccinators had two main concerns. In order to maintain the arm-toarm momentum of vaccination, it was essential that parents returned children for lymph to be drawn off. A refundable deposit of 1s was approved, in August 1801, "as a check upon them to return to intimate what progress the inoculation has made", 80 and was doubled to $2 \mathrm{~s}$ in June 1806 in a probable attempt to maximize returns. ${ }^{81}$ Either amount represented a considerable sum from the wages of the working classes when the weekly

\footnotetext{
${ }^{72}$ I owe this point to Johanna Geyer-Kordesch. Guthrie also states that "as hospitals became available, free vaccination took the place of free treatment, and this was provided throughout the nineteenth century". D Guthrie, A history of medicine, London, Thomas Nelson, 1947, p. 155.

${ }^{73}$ RCPSG 1/1/1/5, fol. 218r; RCPSG 1355/4, Case of The FPSG, with reference to the Acts $43 \mathrm{~d}$ Geo. III. Cap. 56, and 59th Geo. III. Cap. 124. 1820; Hamilton, op. cit., note 8 above, p. 161. The committee comprised Mr McLeod, Mr McArthur and Mr Cooper.

${ }^{74}$ Flinn's introduction to Chadwick's Report, op. cit., note 3 above, p. 48; White, 'Training medical policemen', op. cit., note 6 above, pp. 152-3. Cowan entered the Faculty in 1790 . Duncan, op. cit., note 38 above, p. 265.

${ }^{75}$ Neilson entered the Faculty in 1812 . Duncan, op. cit., note 38 above, p. 272.

${ }^{76}$ Corkindale entered in 1803 . He was appointed as casualty surgeon and medico-legal examiner in criminal cases. Neilson and Corkindale were appointed at some time before 1820 . Duncan, op. cit., note 38 above, p. 269; White, 'Training medical policemen', op. cit., note 6 above, p. 154 .

${ }^{77}$ Easton entered in 1840 , in the year after his
}

appointment. When appointed, he was lecturer in materia medica at Anderson's, and was appointed physician to the Royal Infirmary in 1852 . Duncan, op. cit., note 38 above, p. 288; White, 'Training medical policemen', op. cit., note 6 above, p. 155. For the evolution of forensic medicine in Glasgow, see M A Crowther and B White, On soul and conscience. The medical expert and crime, Aberdeen University Press, 1988.

${ }^{78}$ This is a correction of White, 'Training medical policemen', op. cit., note 6 above, p. 161 fn. 34 which reads 4 April 1832.

${ }^{79}$ RCPSG $1 / 1 / 1 / 6$, pp. $441,445$.

${ }^{80}$ RCPSG $1 / 1 / 1 / 4$, fol. 169v. This was at the suggestion of John Scruton, vaccinator. Another of the medical trustees of Anderson's Institution, he became Professor of Clinical Cases there. Duncan, op. cit., note 38 above, p. 263.

${ }^{81}$ RCPSG $1 / 1 / 1 / 4$, fol. $246 \mathrm{v}$. The first vaccination of 7 July 1806 was performed at the new rate. However, payments of $2 \mathrm{~s}$ and $1 \mathrm{~s}$ were generally mixed until the first across-the-board payment of $2 \mathrm{~s}$ was recorded on 6 October 1806. RCPSG 1/7/5, Faculty Vaccination Register, 3 March 1806 to 21 November 1808 , pp. 35, 55-9, 65-7. 


\section{Vaccination Policy of the FPSG}

expenditure of the lowest-paid between 1810 and 1831 was about 9 s per week. ${ }^{82}$ A committee appointed to find a way to remedy the abuses of vaccine inoculation reported, on 1 April 1806, that the Faculty had vaccinated more than 10,000 children, but of these nearly 2,000 had never returned. ${ }^{83}$ It was convinced that, if a reward could be offered for every spurious case which was subsequently authenticated, the prejudice against vaccination could be refuted. Included among the failures, as things stood, such cases were "the means of throwing undeserved obloquy on vaccination in general; or the endeavours of the Faculty in particular". ${ }^{84}$ The Faculty's other main concern was to prevent the application of those who were able to pay. ${ }^{85}$ It was relatively unsuccessful in redressing either abuse.

In reply to its first letter from the National Vaccine Establishment (NVE), ${ }^{86}$ in December 1810, the Faculty reported: "in this city the practice of vaccination has increased much; for in the greatest number of families soon after the birth of a child it is now almost uniformly vaccinated. To this practice it is believed there are few exceptions except perhaps in the lowest ranks". ${ }^{87}$ This mirrors the attitude prevalent in the rest of Great Britain in the early nineteenth century, where vaccination was readily accepted by the rich and middle classes, but apparently not by the very poor, the harsh reality of whose lives imbued in them a certain fatalism. ${ }^{88}$ Analysis of the occupational groupings in the first vaccination register supports the Faculty's response, revealing that it was mainly artisans and semi-skilled workers, and not the unskilled, who brought their children for vaccination. ${ }^{89}$ Overall, the introduction of vaccination had greatly decreased the mortality from smallpox; inoculation was almost never practised "except in a few rare instances after vaccination-to satisfy those who entertain any apprehension of the person vaccinated being still liable to the small pox". ${ }^{90}$

The FPSG appears to have suffered little from the anti-vaccination lobby which began to make itself vocal in Britain in 1809-10, misrepresenting vaccination as a doubtful

\footnotetext{
${ }^{82} \mathrm{~T}$ R Gourvish, 'The cost of living in Glasgow in the early nineteenth century', Econ. Hist. Rev., 2nd series, 1972, 25(1): 65-80, pp. 65-7. This uses data from the publications of James Cleland (1770-1840), the Glasgow statistician and annalist.

${ }^{83}$ RCPSG $1 / 1 / 1 / 4$, fol. 245 r.

${ }^{84}$ RCPSG $1 / 1 / 1 / 4$, fol. 245 r v.

${ }^{85}$ This is discussed further in the section below on Finance and Funding.

${ }^{86}$ This was a central institution set up by Parliament to promote Jenner's cowpox vaccination under the superintendence of the Royal College of Physicians in London. Sir Arthur Salusbury MacNalty, 'The prevention of smallpox: from Edward Jenner to Monckton Copeman', Med. Hist., 1968, 12: 1-18, pp. 9-10; F F Cartwright, A social history of medicine, London and New York, Longman, 1977, p. 89.

${ }^{87}$ RCPSG $1 / 1 / 1 / 5$, fols. $55 \mathrm{v}, 56 \mathrm{r}$ v, $57 \mathrm{v}$.

${ }^{88} \mathrm{~F}$ B Smith, The people's health 1830-1910,
}

London, Weidenfeld and Nicolson, 1990, pp. 158-9.

${ }^{89}$ Almost a third of the sample in the year 1801-2 are weavers. This is fully analysed in a second paper.

${ }^{90}$ RCPSG $1 / 1 / 1 / 5$, fols. 57v, 58r. In nearby Edinburgh, voluntary public vaccination had been inaugurated three months earlier, in February 1801. Between then and February 1807, the Surgeons of the Vaccine Institution in Edinburgh reported that they vaccinated 7,140 people, 10,525 by April 1809 , and 11,108 by January 1811 . W Farquharson, J Bryce, A Gillespie, J Abercrombie (surgeons), 'Public Dispensary, Edinburgh. Report of the Surgeons of the Vaccine Institution', Edinburgh med. J., 1807, 3: 253-4, p. 253; idem, 'Report of the Surgeons of the Vaccine Institution of Edinburgh for 1809', Edinburgh med. J., 1810, 6: 256-7, p. 256; idem, 'Report of the Surgeons of the Vaccine Institution of Edinburgh, 1810', Edinburgh med. J., 1811, 7: 254. 


\section{Fiona A Macdonald}

security against smallpox, though putting forward the more accurate view that its powers diminished with time. ${ }^{91}$ An anonymous report on vaccination in Glasgow, dated 1 February 1811, said that:

None of those jarring opinions, which have disgraced other parts of the kingdom, are known in Glasgow. The profession universally recommend the practice, and the people almost as universally receive it. The few deaths by small-pox, which have occurred, within these last six years, have been exclusively among recent incomers, and the poorest and most wretched of the Highlanders and Irish. ${ }^{92}$

Dr Reed in Kilmarnock (21 miles south-west of Glasgow) concurred in this conclusion, noting in September 1821, that "Ireland seems the head quarters of small-pox" in his area. ${ }^{93}$ The early nineteenth century was a period of increased emigration from Ireland which had its genesis in a depression in the linen industry in north-east Ulster that coincided with the introduction of power into cotton-spinning in the west of Scotland. In 1819 , approximately 30 per cent of the weaving population in Glasgow, ${ }^{94}$ and about 10 per cent of the city's entire population, was Irish. ${ }^{95}$ The problems of Irish immigration were exacerbated in the 1840 s and 1850 s due to the Potato Famine. ${ }^{96}$ Though nowhere near as extensive, ${ }^{97}$ there was also significant Highland movement to Glasgow during this period, occurring first as a result of clearance, ${ }^{98}$ then as a consequence of decline in the kelp-manufacturing, commercial fishing and whisky-producing industries by the $1820 \mathrm{~s},{ }^{99}$ and finally because of repeated potato famine (1836-50). ${ }^{100}$ However, the greatest irony

91 J Creighton, 'Foundling Hospital, Dublin, 4th Jan. 1810', Edinburgh med. J., 1810, 6: 257-8, p. 257; Smith, op. cit., note 88 above, p. 164. This was not verified until the 1820 s.

${ }^{92} \mathrm{~W}$, 'Vaccination in Glasgow', Edinburgh med. J., 1811, 7: 250. This is unattributed, but was most probably by Robert Watt, for whom see p. 304 below.

${ }^{93} \mathrm{~J}$ Reed, 'Observations on variola, varicella, and modified small-pox', Edinburgh med. J., 1822, 18: 184-91, p. 184.

$94 \mathrm{G}$ Walker, 'The Protestant Irish in Scotland', in T M Devine (ed.), Irish immigrants and Scottish society in the nineteenth and twentieth centuries, Edinburgh, John Donald, 1991, pp. 45-8.

$95 \mathrm{~J}$ Cleland, Enumeration of the inhabitants of the city of Glasgow and its connected suburbs, Glasgow, s.n., 1820, p. 6.

${ }^{96} \mathrm{M}$ Anderson and D J Morse, 'The people', in W Hamish Fraser and R J Morris (eds), People and society in Scotland II, 1830-1914, Edinburgh, John Donald in association with the Economic and Social History Society of Scotland, 1995, pp. 12, 18. There is further discussion of late-nineteenth-century demography in Scotland in M Anderson and D J Morse, 'High fertility, high emigration, low nuptuality: adjustment processes in Scotland's demographic experience, 1861-1914', Popul. Stud. 1993, 47: pt 1, pp. 5-25, pt II, pp. 319-343.

${ }^{97} \mathrm{~T}$ M Devine, 'Urbanisation', in T M Devine and $\mathrm{R}$ Mitchison (eds), People and society in Scotland I,
1760-1830, Edinburgh, John Donald, 1988, pp. 41-3.

${ }^{98} \mathrm{~A}$ discussion of the early phase of clearance can be found in A I Macinnes, 'Scottish Gaeldom: the first phase of clearance', in Devine and Mitchison (eds), ibid., pp. 70-90; the final phase is treated in T M Devine, Clanship to crofters' war, Manchester University Press, 1994, pp. 54-62. A more detailed survey is provided in E Richards, $A$ history of the Highland clearances, 2 vols, London and Canberra, Croom Helm, 1982 and 1985.

99 Devine, Clanship to crofters' war, op. cit., note 98 above, p. 137.

${ }^{100}$ For a brief overview refer to T M Devine, 'Highland migration to Lowland Scotland, 1760-1860, Scott. hist. Rev., 1983, 62: 137-49. For a more extensive study, see R D Lobban, 'The migration of Highlanders into Lowland Scotland $c$. 1750-c. 1890', PhD thesis, University of Edinburgh, 1969. The best discussion of the famine is T M Devine, The great Highland famine, Edinburgh, John Donald, 1988, while the patterns of migration consequent on it are described in C W J Withers, 'Destitution and migration: labour mobility and relief from famine in Highland Scotland 1836-1850', J. hist. Geog., 1988, 14(2): 128-50. Highland migration to Glasgow in the late nineteenth century is considered in $\mathrm{C} \mathrm{W} \mathrm{J}$ Withers and $\mathrm{A} \mathrm{J}$ Watson, 'Stepwise migration and Highland migration to Glasgow, 1852-1898', J. hist. Geog., 1991, 17(1): 35-55. 


\section{Vaccination Policy of the FPSG}

in their movement south was surely in the replacement of one set of abysmal social conditions with another. ${ }^{101}$

The Faculty also blamed the influx of Irish labourers for the prevalence of smallpox "in this part of the country" throughout 1811. This was an obvious attempt on their part to justify their failure to control outbreaks of the disease in spite of having performed 1,544 vaccinations in the previous year. They could only insist that they knew of no instance where someone vaccinated had contracted smallpox. ${ }^{102}$ The Faculty reiterated the positive effects of vaccination on smallpox mortality, reporting to the NVE, in the following year, that there had been only 24 deaths by smallpox in 1812 . As far as they were concerned, their work had largely been successful, and they were convinced that "the confidence in the preventive power of Vaccination continues unabated". ${ }^{103}$

Not content with its work in the city, the Faculty also sent vaccine matter to practitioners in rural districts in order "to promote the extensive diffusion of vaccination" throughout its jurisdiction. ${ }^{104}$ The procedure understandably took longer to become established outside the city. In replies to the questionnaire in the 1811 census, the 66 (out of 634) enumerators who mentioned vaccination most commonly identified 1803 as the year in which it was introduced to their parishes. This had much to do with its being sanctioned, in May of that year, by the General Assembly of the Church of Scotland which led to some ministers acting as vaccinators in rural areas. ${ }^{105}$ None the less, it was not introduced into Stranraer, on the Faculty's south-western boundary, until 1806, some five years after its introduction to Glasgow. ${ }^{106}$ The success of vaccination in these areas was dependent not only on the purity of the lymph available, but also on the ability of vaccinators who were not always medically trained. In the village of Kilmaurs in Ayrshire, there were 60 cases of smallpox between April 1820 and September 1821. Dr Reed, in nearby Kilmarnock, noted that one sixth had never been vaccinated but he was more concerned, in those who had, about "the imperfect manner in which vaccination had been performed. A slight scratch, in some scarcely visible, was all that remained to mark where the vesicle had been". This he put down to the fact that "in the instances now

\footnotetext{
${ }^{101}$ See M Gray, 'The Highlands, 1800-1860: growing stress and crisis', in idem, Scots on the move: Scots migrants, 1750-1914, Edinburgh, The Economic and Social History Society of Scotland, 1990. For Highlanders in Glasgow during this period, see J MacKenzie, 'The Highland community in Glasgow in the nineteenth century: a study of nonassimilation', $\mathrm{PhD}$ thesis, University of Stirling, 1987.

${ }^{102}$ RCPSG 1/1/1/5, fol. 81r. Second report to the NVE, letter dated 8 February 1812.

${ }^{103}$ RCPSG $1 / 1 / 1 / 5$, fols. $105 \mathrm{v}, 106 \mathrm{r}$.

${ }^{104}$ RCPSG $1 / 1 / 1 / 5$, fol. 81 r. Supply of lymph to licentiates seems to have been temporarily stopped in 1818 (probably as a result of declining attendance) because Mr McLeod moved on 3 November that licentiates be allowed to come to the Hall for vaccine matter as formerly. He later withdrew his motion. RCPSG 1/1/1/5, fol. 217r. A note of the number of charges of lymph supplied to members and others on
}

each vaccination day is recorded from 1841. On 4 October 1841, for instance, 27 charges of lymph were given out. RCPSG $1 / 7 / 11$, p. 148 . However, the earliest surviving list of named members and licentiates supplied with glasses of lymph (commonly two glasses), dates from much later in 1852. RCPSG $1 / 7 / 11$, Faculty Vaccination Register, 30 January 1832 to 19 March 1854, back inside cover.

${ }^{105}$ Flinn (ed.), op. cit., note 29 above, pp. 392-3. For the original address from the Edinburgh surgeons which led to the Church sanction, see Royal College of Physicians Edinburgh, Address to the Reverend the Ministers of the Church of Scotland, from the Managers of the Vaccine Institution at Edinburgh, Edinburgh, Bell and Bradfute, 1803.

$106 \mathrm{~J}$ Orgill, 'Observations on the measles and small-pox, that prevailed epidemically in Stranraer, in the autumn of 1829', Glasgow med. J., 1st series, 1831, 4: 351-7, p. 354. 


\section{Fiona A Macdonald}

mentioned, the village midwife and teacher had been almost universally the operators". ${ }^{107}$ While it is hard to hold up inefficient vaccination as a progressive public health measure, it emphasizes the value of the Faculty's own institution staffed by licensed medical practitioners.

Inadequacies notwithstanding, vaccination was accepted relatively quickly in and around Glasgow, where the Faculty promoted its work in the press and by distributing handbills. ${ }^{108}$ In May 1812, some children, who had already been vaccinated, were inoculated by a Glasgow surgeon sceptical of the procedure, and the Faculty felt compelled to investigate rumours that the virus had taken effect, ${ }^{109}$ in case this resulted in a dangerous withdrawal from vaccination. ${ }^{110}$ The conclusion of a public meeting that "they remain as fully convinced as ever of the inestimable value of the cowpox" was published in a newspaper advertisement. ${ }^{111}$

Robert Watt, MD, Faculty President from 1814 to 1816 and one of the main advocates of the vaccination programme, was the first to make a detailed, comparative study of smallpox mortality in relation to other childhood diseases. ${ }^{112}$ He published his Treatise on the history, nature and treatment of chincough, in 1813, with an appendix which compared the number of deaths in children under ten before, and after, the introduction of vaccination. ${ }^{113}$ The findings from Watt's analysis of 30 years of burial registers of the city of Glasgow between 1783 and 1812 were conclusive. Prior to vaccination more than 50 per cent of children died before they were ten years old, a third of that number from smallpox. Yet, taking the average of several post-vaccination years, there were nearly the same number of deaths in the under-tens, in spite of the fact that by 1813 "above fifteen thousand had been inoculated publicly at the Faculty Hall, and perhaps twice or thrice that number in private practice". According to this estimate, between 30,000 and 45,000 children must have been vaccinated privately. ${ }^{114}$ Death by smallpox did drop because of vaccination, but, having been saved, some of the weak and unhealthy fell victim to measles. His ultimate conclusion was that "the deaths under ten years of age have not been diminished by the removal of the Small Pox". 115 Based on statistical evidence, Watt's conclusions were not easy to deny and prompted an extremely negative reaction from Edward Jenner:

In short, he says, or seems to say, that we have gained nothing by the introduction of cowpox; for that the measles and smallpox have now changed places with regard to their fatal tendency. Is not this shocking? Here is a new and unexpected twig shot forth for the sinking anti-vaccinationist to cling to. But mark me-should this absurdity of Mr Watt take possession of the minds of the people, I am already prepared with the means of destroying its effects, having instituted an inquiry through

\footnotetext{
${ }^{107}$ Reed, op. cit., note 93 above, p. 187 . By the time of writing, a regular practitioner was in the area.

${ }^{108}$ In August 1813, $£ 1$ 1s was minuted for the carriage of cowpox pamphlets. RCPSG $1 / 1 / 1 / 5$, fol. $119 r$.

${ }^{109}$ It may have done, had the primary vaccination been performed when they were infants.

${ }_{110}$ Duncan, op. cit., note 38 above, pp. 154-5.

${ }^{111}$ RCPSG 1/1/1/5, fol. 91r.
}

\footnotetext{
${ }^{112}$ Mercer, Disease, mortality and population, op. cit., note 22 above, p. 184 fn. 43.

${ }^{113}$ Archibald L Goodall and Thomas Gibson, 'Robert Watt: physician and bibliographer,' J. Hist. Med. allied Sci., 1963, 18(1): 36-50, pp. 38-40, 43.

114 This is the only figure which estimates the number of vaccinations performed in private practice in Glasgow in the early nineteenth century:

115 Watt, op. cit., note 58 above, Appendix, pp. $333-5,341-2,376-7,383$.
} 


\section{Vaccination Policy of the FPSG}

this populous town [Cheltenham] and the circumjacent villages, where, on the smallest computation, 20,000 must have been vaccinated in the course of the last twelve years by myself and others. Now it appears that during this period there have been no such occurrence as fatal epidemic measles. ${ }^{116}$

Jenner grossly misjudged Watt's intentions, but following his lead the Edinburgh Medical Journal published a review of the NVE's report for 1813 which put the results in Glasgow down to "some local or temporary peculiarity". 117 Watt's analysis certainly appears convincing, but there had been two epidemic peaks in measles in 1808 and 1811-12 118 which, retrospectively, can be seen to have biased the longterm relevance of his conclusion. In reality, measles never reproduced the overall mortality of smallpox. ${ }^{119}$

\section{Finance and Funding}

It would be useful to be able to assess what its public vaccination programme cost the Faculty at any time between 1801 and 1863 but, unfortunately, no information on this survives. Separate account books are not extant for this period, and the annual accounts (as transcribed into the minutes) specify only the amounts taken in cowpock forfeits. Similarly, the vaccination registers reveal only the sum of weekly forfeits and additional small amounts paid out, for example, for court plaster. There must have been substantial costs in publicity and advertising, in remunerating the vaccinators and in maintaining a room solely for vaccination, but only fragments of this financial information remain. For instance, on 3 December 1804, the Faculty allowed Rice Jones $£ 3$ "for his past trouble in the Vacine Inoculatio[n]". ${ }^{120}$ Very occasionally, it paid for the carriage of lymph from the NVE when its own supplies failed, as on 21 January 1850 when eleven children were "Vaccinated with lymph from London". ${ }^{121}$ The FPSG tried to mitigate costs in a number of ways, mainly by attempting to limit vaccination free of charge to the poor, but also by encouraging other civic and national institutions to share the costs-largely unsuccessfully. The introduction of fees (as distinct from the deposit exacted from the poor) was effected on 4 November 1802 when the Faculty authorized the vaccinators to charge a sum of not more than $5 \mathrm{~s}$ for each vaccination at the Hall. This seems to indicate

\footnotetext{
${ }^{116}$ Paul Saunders, Edward Jenner: the Cheltenham years 1795-1823, Hanover NH and London, University Press of New England, 1982, pp. 312-13.

${ }^{117}$ Goodall and Gibson, op. cit., note 113 above, p. 43; 'On the influence of vaccination upon population', Edinburgh med. J., 1814, 10: 89-97, pp. 90-1, 95-6.

118 Watt, op. cit., note 58 above, pp. 368, 371-2; Flinn (ed.), op. cit., note 29 above, pp. 393-4.

${ }^{119}$ Flinn (ed.), op. cit., note 29 above, p. 419 . For example, in the late $1830 \mathrm{~s}, 6.5$ per cent of all deaths were from measles, ibid., p. 394, a little over a third of the 19 per cent mortality from smallpox shown by Watt in the period 1783 to 1800 . This is backed up
}

\begin{abstract}
by the Swedish evidence presented by Mercer who showed that the composite mortality from smallpox, measles, diphtheria and scarlet fever between 1801 and 1811 was still much lower than in the period before the introduction of vaccination, with the reduction in smallpox mortality contributing most to the decline. Disease, mortality and population, op. cit., note 22 above, pp. 52, 230.

${ }^{120}$ RCPSG $1 / 1 / 1 / 4$, fol. 219 r.

${ }^{121}$ RCPSG $1 / 7 / 11$, p. 221 . This was a rare occurrence. The vaccinator went to the lengths of pasting the general letter which he received with the lymph, dated 18 January 1850 , into the back of this register.
\end{abstract}




\section{Fiona A Macdonald}

that private patients were vaccinated there, but they are not designated as such in the registers until $1837 .{ }^{122}$ The poor were still to be vaccinated gratis. ${ }^{123}$

However, the FPSG facility did not function like most vaccine institutions in England, which operated as charity dispensaries. The Royal Jennerian Society, for example, offered free vaccination to "persons of all ages", officially the poor, who had to have written notice from a subscriber or Society official. ${ }^{124}$ Since the vaccination station was an arm of the FPSG and not set up by public subscription, there seem to have been more problems in policing access to Faculty Hall. ${ }^{125}$ In order to redress this grievance, in 1804 the Faculty appointed a committee to devise a regulation "to rid the Faculty of the trouble of innoculating [sic] for the Cow pox gratis the children of those who are well able to pay for it". 126 Reporting back, the committee decided to advertise its resolution: "That only the Children of the labouring Poor who are supposed unable to pay for Inoculation will after the first Monday of September next be Inoculated for the Cowpox at the Faculty Hall and such persons must bring a Certificate of their inability to pay or a ticket of Admission". 127

The Faculty continued its efforts to have the costs of free public vaccination subsidized by other agencies. In 1806, a committee was appointed to draw up a plan for a vaccine institution to be supported by the public. The proposals (to set up a Jennerian Society to further vaccination in the city $)^{128}$ were rejected by a large majority. ${ }^{129}$ In 1812 the NVE were approached for details of money available from public funds to promote vaccination, but Mr Moore replied that the Board "had nothing in their power respecting any aid from Government". ${ }^{130}$ Neither is there any indication that the Faculty received funding from Glasgow Town Council. The surviving evidence indicates that the Faculty met the entire bill for the programme itself from its own assets. ${ }^{131}$

Taking a tougher line with those not entitled to free vaccination, the Faculty reconsidered the entire issue of funding, in 1815 , by appointing a committee to report on the fee paid for vaccination. This concluded that only a small proportion of those who brought their children to the Hall for vaccination were objects of charity, and that while every inducement ought to be given to the poor to vaccinate their children "means should

\footnotetext{
122 The first case specifically identified as private is recorded on 28 August 1837-"Dorothy

Forthingham 4 months. Private Case. No pledge". RCPSG 1/7/11, p. 100.

${ }^{123}$ Sums earned by vaccination were to go to the library funds. The library subsequently received $£ 10$ 10s from vaccinating for cowpox in the period to 5 December 1803, a further $£ 63$ s to 13 March $1804, £ 33$ s to May 1804 , and $£ 7$ on 2 September 1805. RCPSG $1 / 1 / 1 / 4$, fols. 190r, 218v; RCPSG 1/7/4, Faculty Vaccination Register, 5 March 1804 to 24 February 1806 , p. 220 . Similar sums were still being recorded over ten years later. RCPSG $1 / 7 / 8$, p. 222; RCPSG 1/7/9, p. 109.

124 R B Fisher, Edward Jenner 1749-1823,

London, André Deutsch, 1991, p. 144.

${ }^{125}$ I owe this point to Deborah Brunton.

${ }^{126}$ RCPSG $1 / 1 / 1 / 4$, fol. 211 r.
}

\author{
${ }^{127}$ RCPSG $1 / 1 / 1 / 4$, fol. 213 r. \\ ${ }^{128}$ Details are not specified in the minutes but a \\ later report of the committee on vaccine inoculation, \\ of 1 April 1806, indicates that they planned to set up \\ a Jennerian Society, comprising the Magistrates, \\ Merchants and Trades Houses, General Sessions and \\ public charitable Institutions, and subscribing \\ individuals, to promote vaccination in the city. \\ There is no evidence that this came into being, but a \\ distinctly paternalistic attitude was anticipated for it, \\ in that it could withhold all public charity from \\ paupers who refused vaccination. RCPSG 1/1/1/4, \\ fol. 245v. \\ ${ }^{129}$ RCPSG $1 / 1 / 1 / 4$, fols. 243v, 244r v. \\ 130 RCPSG $1 / 1 / 1 / 5$, fol. $81 \mathrm{v}$. \\ 131 James Cleland, The annals of Glasgow, 2 vols, \\ Glasgow, J Hedderwick, 1816, vol. 1, p. 213.
}




\section{Vaccination Policy of the FPSG}

be taken to prevent others from using the charity". ${ }^{132}$ Advertisements were to be placed in the press calling on clergymen ${ }^{133}$ and elders to persuade the poor to bring their children for free vaccination in the Hall, while emphasizing that the Institution was only for the poor. No mention was made of fee-paying patients. Adopted unanimously, the report also proposed the first proper means of regulating the system. A card system would be introduced to "prevent confusion and the intrusion of improper persons into the Hall". Any member of the Faculty who sent his apprentices or servants for cowpox matter had to send a card with them, and they were not to be admitted without one. ${ }^{134}$

The Faculty was also behind the first private vaccination initiatives in Glasgow. Two FPSG members, Messrs William Anderson ${ }^{135}$ and Archibald Millar, ${ }^{136}$ opened the Cowpox Dispensary, in 1804, opposite the Exchange. Surgeons attended there on Wednesdays and Saturdays, between eleven and one o'clock, where they vaccinated children privately for the sum of $2 \mathrm{~s} 6 \mathrm{~d}$ each. The dispensary targeted those resentful of charity: "By means of this institution, it is hoped, that the blessings of vaccination will be more widely disseminated, by inducing a number of people, in circumstances, although far from wealthy, yet not willing to be accounted in need of public charity, to inoculate children at such a trifling expence". ${ }^{137}$ It also made provision for vaccination to be offered as a subsidiary employment benefit: "At the Dispensary, tickets are also issued, to be purchased by masters of public works, or others who wish to make a present of that value to those of their workmen, who, from a numerous family or any other reason, may yet be unable to pay the small sum above mentioned". ${ }^{138}$ At about the same time, James Watt ${ }^{139}$ opened the Subscription Dispensary at No. 17, Gallowgate, whose design was "to afford the sick poor at their own houses, medicine, advice, and inoculation to their children" on subscription. ${ }^{140}$

Fees recommended to members for private vaccination were also fixed, on 3 July 1809 , in the FPSG table of rates:

$\begin{array}{llll}\text { Class } 1 & \text { Class } 2 & \text { Class } 3 & \text { Class } 4 \\ £ 33 \mathrm{~s} & £ 22 \mathrm{~s} & £ 11 \mathrm{~s} & 10 \mathrm{~s} 6 \mathrm{~d}^{141}\end{array}$

\footnotetext{
${ }^{132}$ RCPSG $1 / 1 / 1 / 5$, fol. 141v, 144r.

${ }^{133}$ Clergymen exercising social consciences had played an early part in establishing the status of those deigned worthy of free treatment. When the two sons of Peter Brown, soldier in the Gorbals, came to be vaccinated on 2 September 1805 , they did not pay "but brought a line from [the] Gorbal's Minister". RCPSG 1/7/4, pp. 247-8.

${ }^{134}$ RCPSG $1 / 1 / 1 / 5$, fol. 144r v.

135 William Anderson was Professor designate of Obstetrics at Anderson's Institution by the terms of Anderson's will. He entered the Faculty in 1790. Duncan, op. cit., note 38 above, p. 265.

${ }^{136}$ Archibald Millar had entered the Faculty three years earlier in 1800 . He practised for a number of years in Anderston, and later became surgeon to the 47th Regiment of Foot, which took him to India. Duncan, op. cit., note 38 above, p. 268.
}

\footnotetext{
137 James Denholm, The history of the city of Glasgow and suburbs, 3rd ed., Glasgow, A Macgoun, 1804, pp. 383-4. Note that Denholm's sister, Margaret, was married to James Somers, who had entered the Faculty in 1776, and died shortly afterwards, leaving his widow and daughters as pensioners of the Faculty. Duncan, op. cit., note 38 above, p. 261.

${ }^{138}$ Denholm, op. cit., note 137 above, p. 384.

139 James Watt graduated MD from Glasgow University in 1796. W Innes Addison, A roll of the graduates of the University of Glasgow from 31st December, 1727 to 31 st December, 1897, Glasgow, James MacLehose, 1898, p. 635.

${ }_{140}$ Denholm, op. cit., note 137 above, pp. 384-5. For example, at a distance of one mile, the subscription was one guinea per patient annually.

${ }^{141}$ RCPSG 1/1/1/5, fol. 26r.
} 


\section{Fiona A Macdonald}

This was primarily a determination of ability to pay based on social class. The sliding scale was implemented as part of an early nineteenth-century attempt to standardize fees charged by doctors in private practice in Scotland. ${ }^{142}$ All these sums represent a significant increase on the $5 \mathrm{~s}$ charged by the Faculty for private vaccination in 1802 , and the $2 \mathrm{~s} 6 \mathrm{~d}$ charged by the Cowpox Dispensary. ${ }^{143}$ Though Robert Watt's statement in 1812 provides the only numerical estimate of the extent of private vaccination in Glasgow, the work of these dispensaries and the setting of rates for FPSG members indicates that vaccination was an important aspect of private medical practice.

\section{II}

\section{Decline in Public Vaccination after 1820}

Towards the end of the second decade of the nineteenth century, enthusiasm for public vaccination in Glasgow was waning. 1815 saw a tightening of the regulations for vaccinators with a motion carried in December that those failing to provide a locum were to be fined $10 \mathrm{~s} 6 \mathrm{~d}$ each time. ${ }^{144}$ None the less, this did not prevent continued absences, ${ }^{145}$ and even the zeal of the initiator of the vaccination programme seems to have abated by October 1819 when the recorder noted that "Dr James Menteath [sic] has been absent three times and not provided a substitute". ${ }^{146}$ Such attempts at regulation did little to resurrect enthusiasm for the programme, attitudes to which had become lackadaisical. The Faculty's Cowpox Fund was deficient in the sum of $£ 11$, owed by four previous vaccinators when they demitted office in June 1817, and the clerk was ordered to write to all four "threatening prosecution against them jointly and severally for the deficiency". ${ }^{147}$

The Faculty radically overhauled its vaccination policy in 1820 due to a marked lull in numbers availing themselves of the charity. In that year, only 345 children were vaccinated, ${ }^{148}$ and yet another committee was appointed to rationalize the programme. This made the vaccinator an office bearer and examiner and the vaccinatorship an annual appointment. ${ }^{149}$ It was, henceforth, to be voluntary (and not chosen monthly by rotation), which afforded the vaccination programme at least a degree of autonomy. A superintending committee or board of vaccination was set up (of which the vaccinator was never to be convenor or president) to visit the Hall once a month while vaccination was in

\footnotetext{
142 This had arisen because of the difficulty experienced by the public in estimating whether the fees charged by doctors were fair. See Hamilton, op. cit., note 8 above, pp. 171-2. The Faculty first published their prices in 1800 . See Glasgow University Library Special Collections (hereafter GUL Spec. Colls.), Mu Add 44, 'Prices of medicines and attendance fixed by the Faculty of Physicians and Surgeons in Glasgow. Sixth December, 1799', Glasgow, s.n., 1800.

143 See above p. $305,307$.

144 RCPSG $1 / 1 / 1 / 5$, fol. 162 r.

145 The recorder noted, in 1816, that he: "Waited in the Hall on Monday 8th April till half past twelve, and none of the Inoculators were present".
}

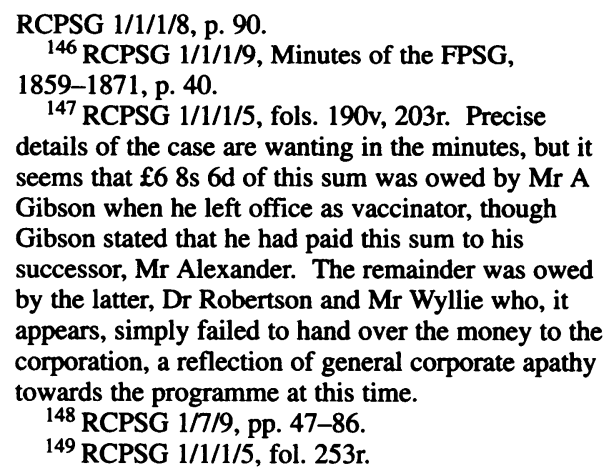
seems that $£ 68 \mathrm{~s} 6 \mathrm{~d}$ of this sum was owed by Mr A Gibson when he left office as vaccinator, though Gibson stated that he had paid this sum to his successor, Mr Alexander. The remainder was owed by the latter, Dr Robertson and Mr Wyllie who, it appears, simply failed to hand over the money to the corporation, a reflection of general corporate apathy towards the programme at this time.

148 RCPSG $1 / 7 / 9$, pp. 47-86.

${ }^{149}$ RCPSG $1 / 1 / 1 / 5$, fol. 253 r. 


\section{Vaccination Policy of the FPSG}

progress "to ascertain the genuin[ne]ess of the vaccine verus, and regulate accordingly". ${ }^{150}$ Eventually, in August 1823, dispensation from service as vaccinators was given to all who had been Faculty members for 35 years or had served as President. ${ }^{151}$ The deposit was reduced from $2 \mathrm{~s}$ to its former rate of $1 \mathrm{~s}$, though this was not achieved until almost a year after the committee's recommendations that it be done. If effected as an incentive to encourage people to bring their children for vaccination after the disastrous showing in 1820 , this measure failed. ${ }^{152}$

In January 1822, a final committee appointed to consider the state of the Cowpox inoculation Establishment ${ }^{153}$ reported:

We find that the number of children brought to the Hall has been gradually diminished, in consequence of which there is often no choice of Vaccine Lymph and therefore failures of the process frequently happen. This decrease in number may in part be attributed to another Vaccine Institution, situated in a more convenient part of the City, which has, by various means, more publicity given to it, and where the pecuniary deposit has all along been less than what has, till of late, been required by the Faculty. 154

This other Vaccine Institution was the Glasgow Cowpock Institution, founded on 28 August $1818,{ }^{155}$ by "a number of medical gentlemen in this city" who "formed themselves into a Society for Vaccinating the Children of the Poor gratis". Though the 1817-19 smallpox epidemic scarcely affected Glasgow, there was widespread depression in trade and commerce, and this new institution may have addressed a need for cheaper vaccination. Located in St Andrew's Square, a committee attended the Cowpock Institution Hall each Friday to vaccinate. Faculty Hall, at this time, was in St Enoch's Square, a short distance to the west. The Cowpock Institution vaccinated 146 children in the first four months of its operation, ${ }^{156}$ and asked for a $1 \mathrm{~s}$ returnable deposit, half the rate then charged by the Faculty. In certain cases, this was dispensed with on production of a "certificate of poverty from a minister, elder, or a member of the society". The Institution also corresponded with the NVE. ${ }^{157}$ It not only vied with the FPSG on vaccination but ultimately challenged its monopolistic control of medical affairs in Glasgow. A meeting of medical rebels, dissatisfied with its high fees, strict enforcement of boundary jurisdictions, and compulsory membership of the Widows' Fund, met in the Cowpock

\footnotetext{
${ }^{150}$ RCPSG $1 / 1 / 1 / 5$, fol. $253 \mathrm{v}$.

${ }^{151}$ RCPSG 1/1/1/6, Minutes of the FPSG, 1821 to 1835 , p. 137.

152 RCPSG $1 / 7 / 9$, pp. 109-20.

153 RCPSG 1/1/1/6, p. 64.

154 RCPSG $1 / 1 / 1 / 6$, p. 65.

${ }^{155}$ This is a correction of Duncan, op. cit., note
} 38 above, p. 154, and Flinn's more recent work, op. cit., note 29 above, p. 395 . Duncan's date (1813) was from Cleland's Enumeration of the inhabitants of Glasgow, Glasgow, John Smith, 1831, but this appears to have been a printer's error which was also repeated in the 1832 second edition used by Flinn. Neither Cleland, op. cit., note 131 above, vol. 1 , nor his 1817 abridgement of the same, mention any institution other than the Faculty vaccinating. However, the Cowpock Institution is referred to in

\author{
Cleland's The rise and progress of the city of \\ Glasgow, Glasgow, James Brash, 1820, p. 199, \\ where its foundation is dated 1818 , and also in his \\ Enumeration of the inhabitants of Scotland, \\ Glasgow, James Lumsden, 1823, p. 22, where the \\ date is also 1818. The later date is closer to the first \\ mention of the Institution in the FPSG minutes in \\ 1822. \\ ${ }^{156}$ Cleland, ibid., 1820, p. 199; Creighton, op. \\ cit., note 33 above, pp. 571, 582; Duncan, op. cit., \\ note 38 above, p. 108. Figures are for 28 August \\ 1818 to 1 January 1819 . \\ ${ }^{157}$ Cleland, ibid., 1820 , p. 199. The NVE \\ continued its work until the passing of the \\ Compulsory Vaccination Act in 1853. The Jenner \\ Society, 'Antivaccination propaganda: the bane and \\ its antidote', Br. med. J., 1902, ii: 50-1, p. 50.
}




\section{Fiona A Macdonald}

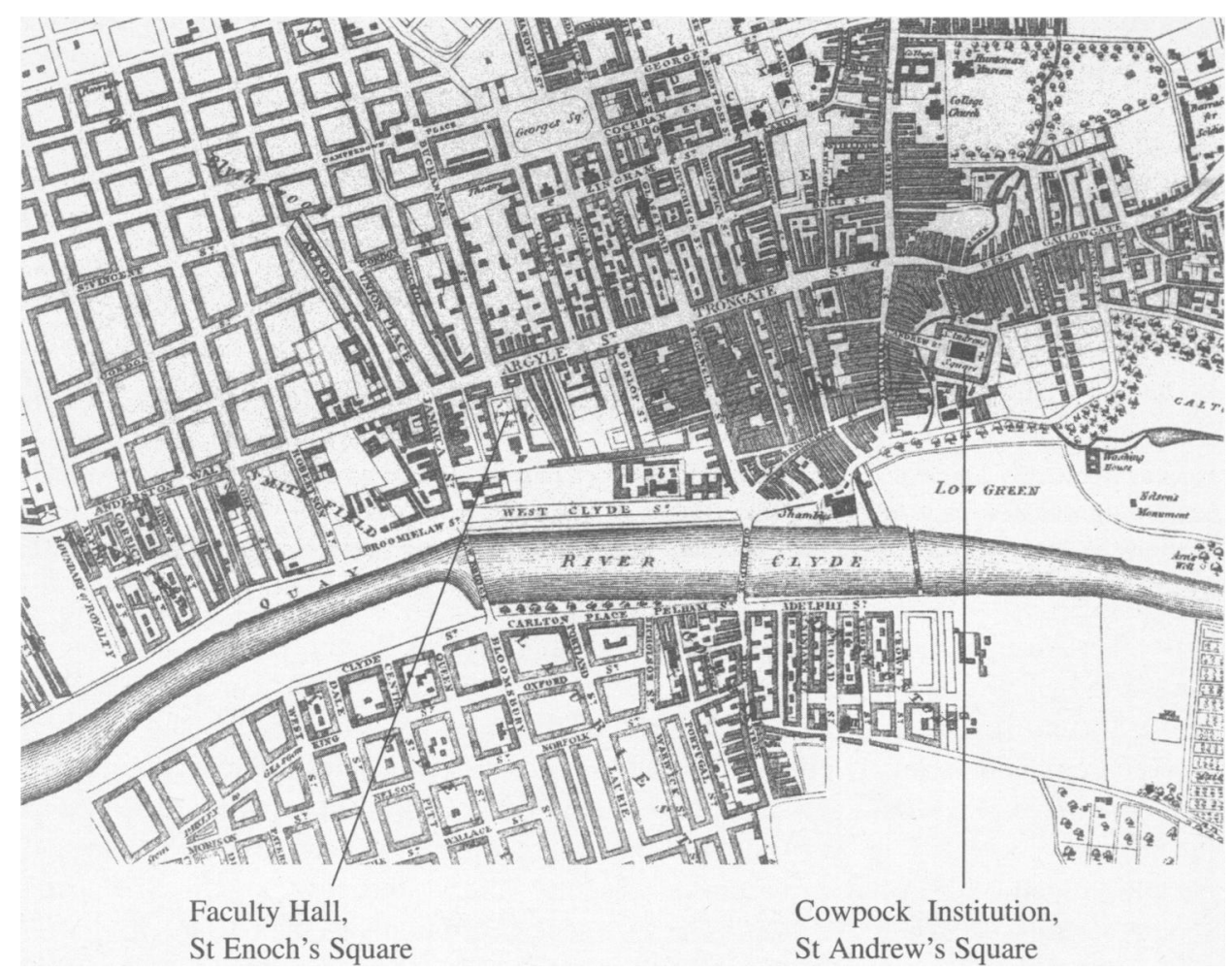

Figure 2: Map of the city and suburbs of Glasgow in 1808, by Peter Fleming. (Source: John Gunn and Marion I Newbigin, The city of Glasgow, Edinburgh, Royal Scottish Geographical Society, 1921, map 5, opp. p. 72.)

Institution Hall on 1 October 1825 and formed an association under the title 'The Glasgow Faculty of Medicine', deliberately chosen to cause confusion. Holding their monthly meetings on a Friday, they became known as the "wee Faculty" ${ }^{158}$ It was presumably for this reason that Cleland was at pains to point out that the Vaccination Society was "unconnected with the Faculty of Physicians and Surgeons". 159 They announced, in 1835, that "The object of this Institution is to extend the benefit of Vaccination gratis to all classes of the community". ${ }^{160}$ In this, it aimed to go one better than its rival, the FPSG.

None the less, the existence of the Cowpock Institution could not entirely account for the lack of attendance at the Faculty Hall because vaccinees at both institutions did not equal those who once used to attend the Hall. Both complained of a low attendance. The committee on the Cowpox inoculation Establishment concluded that private vaccination

${ }^{158}$ RCPSG $1 / 11 / 15$, Minutes of the Glasgow Faculty of Medicine, 1824-1907, p. 1; A J Bunch, Hospital and medical libraries in Scotland, Glasgow, Scottish Library Association, 1975, p. 49. The Vaccination Society probably formed the backbone of the "wee Faculty", which will be the subject of a future paper.
${ }^{159}$ Cleland, 1820, op. cit., note 155 above, p. 199.

${ }^{160}$ The Western Supplement to the Edinburgh and County Almanac of Scotland for 1835. Comprising lists connected with the city of Glasgow, and the western counties of Scotland, Edinburgh, Oliver and Boyd, Glasgow, David Robertson, 1835, p. 58. 


\section{Vaccination Policy of the FPSG}

was much more extensively practised than formerly "when our practice here was at its highest pitch" but that vaccination had been in general decline for some time. This was doubly unfortunate, because "public Vaccination affords a ready supply of lymph for the private practice of the members". 161 Only two children presented for vaccination on 31 December 1821: "These two were vaccinated with matter kept on glasses for eight days". ${ }^{162}$ The situation did not improve. John MacFarlane, an FPSG member and Senior District Surgeon to the City Poor, tried to pinpoint the cause, reporting in 1827 that : "There exists at present among the poorer classes, an increasing carelessness and aversion to vaccination, from a belief, that it does not afford adequate protection against the varioloid disease", ${ }^{163}$ which was, of course, true. Unfortunately, causes of death are not specified in the mortality figures between $1812,{ }^{164}$ and 1835 , the beginning of official recording, ${ }^{165}$ so there is no accurate means of proving this decline. The period from 1817 to 1831 also coincides with a general decline in real income for the unskilled and semiskilled labour force which made it more difficult for poor families to release money for the vaccination deposit. ${ }^{166}$

Subsequently approved, the remedies suggested by the committee to reinvigorate the programme were four-fold. The first two-advertising in the newspapers and making annual reports of the progress of vaccination in the Hall-represent no deviation from established policy. It recommended, third, that both arms be punctured so that two pustules resulted, "one for the supply of matter, the other to remain entire, as a greater security for the constitutional affection". Fourth, lymph was to be drawn only by the vaccinators since mothers were deterred from bringing their children to the Hall when it was removed by very young men (presumably apprentices or students), who destroyed the vesicle. ${ }^{167}$ This also reassured those parents who thought that removing lymph reduced the immunity conferred. ${ }^{168}$ By 1831 , most vaccine institutions left at least one vesicle intact, to go through all the stage of the disease, which practice The Glasgow Medical Journal reported "is attended to by many practitioners in this city". 169

The Faculty had every reason to be concerned about the decline in vaccination in the city. When Mr George Watson ${ }^{170}$ delivered a paper on smallpox to the Glasgow Medical Society ${ }^{171}$ in 1823 , it was in a climate of increasing incidence of the disease: "Small pox

${ }^{161}$ RCPSG 1/1/1/6, pp. 65-6.

162 RCPSG $1 / 7 / 9$, p. 129.

163 John MacFarlane, 'Report of the diseases which prevailed among the poor of Glasgow, during the autumn of 1827', Glasgow med. J., 1st s., 1828, 1: 97-109, p. 105. Watt.

${ }^{164}$ This was the final year of the data extracted by

${ }^{165}$ Dr John Charles Steele, 'Remarks on the increase of small-pox in Glasgow', Glasgow med. J., 3rd series, 1853, 1: 59-74, p. 59.

${ }^{166}$ Gourvish, op. cit., note 82 above, pp. 76, 78; J $\mathrm{H}$ Treble, 'The standard of living of the working class', in People and society in Scotland I, op. cit., note 97 above, pp. 204-6; R A Cage, 'The standard of living debate: Glasgow, 1800-1850', J. econ. Hist., 1983, 43(1): 175-82, p. 182.

${ }^{167}$ RCPSG 1/1/1/6, pp. 66-7.

\footnotetext{
${ }^{168}$ I owe this point to Deborah Brunton.

169 Orgill, op. cit., note 106 above, p. 356 fn.,
} editor's comment.

${ }^{170}$ Watson entered the Faculty in 1812 and was later its President in the year 1845-46. Duncan, op. cit., note 38 above, p. 272.

${ }^{171}$ For the most recent discussion of the Glasgow Medical Society and its role, see D A Dow and K C Calman (eds), The Royal Medico-Chirurgical Society of Glasgow, Glasgow, Royal MedicoChirurgical Society, 1989. The surgical part of the title was dropped at the second meeting in 1814 due to the friction between the FPSG and Glasgow University over the rights of University graduates in medicine to practise surgery. W Downie, 'The Medico-Chirurgical Society of Glasgow, 18141907', Glasgow med. J., 6th s., 1907, 5: 321-98, pp. 323-4. 


\section{Fiona A Macdonald}

has again and again of late been epidemic, and many of those who had undergone vaccination in the most approved and satisfactory manner have been subjected to its baneful influence". Nevertheless, in Watson's opinion, failures were greatly exaggerated both in number and degree. Many of those who had recently had smallpox had neither been inoculated nor vaccinated, while many more had been vaccinated in a slovenly fashion. Significantly, however, the disease had been ameliorated in post-vaccinal cases which was an incalculable contribution to public health. ${ }^{172}$ Watson expressed an opinion, four decades before the Scottish Vaccination Act was passed, that "the extinction of small pox will not be accomplished unless the subject be taken up by the Legislature". He referred mainly to compulsory vaccination of the unvaccinated, but also to the continued practice, in some districts, of "inoculation with variolous matter", a statement which contradicts the Faculty's optimistic reports to the NVE in the previous decade that inoculation was largely discontinued. ${ }^{173}$ This revival of interest in inoculation seems to have occurred in the 1820 s when some practitioners realized that the protection afforded by vaccination had a finite time-span, and that there could be secondary eruptions of smallpox.

By the 1830 s, the burden of free vaccination had been assumed by a number of institutions. Besides the FPSG and the Cowpock Institution, Glasgow University Faculty of Medicine began public vaccination on 18 January 1828 and, according to official statistics, these institutions had performed 39,397 vaccinations between them since 1801. ${ }^{174}$ Though there were now three stations vaccinating free of charge-which indicates the importance of the procedure-none the less, the early enthusiasm for vaccination in Glasgow was not sustained, and the introduction of causes of death in the Mortality Bills from 1835, provides ample evidence of the ravages of smallpox in the under-fives. Between 1835 and 1842, the mortality rate from smallpox in Glasgow was nearly 2 per cent higher than in London though there was an overall decrease in the rate in the city itself between 1836 and 1845 . Contemporaries drew attention to the link between trade depression in Glasgow and epidemics of infectious diseases, particularly in 1836. Figures for the next period were worse. ${ }^{175}$

Assessing the state of smallpox in Glasgow in 1853, Dr John Steele, Superintendent at the Royal Infirmary, demonstrated a distinct increase in smallpox mortality in Glasgow between 1846 and $1852 .{ }^{176} \mathrm{He}$ could only conclude that vaccination had not been as

\footnotetext{
172 RCPSG 2/1/12, Essays read before the Glasgow Medical Society, IX, No. 6, pp. 22-3.

${ }^{173}$ RCPSG 2/1/12, IX, 6, p. 24.

$174 \mathrm{~J}$ Cleland, Enumeration of the Inhabitants of the city of Glasgow and County of Lanark, 2nd ed., Glasgow, John Smith, 1832, p. 22. The FPSG had vaccinated 30,982; the Cowpock Institution 6,969; the Faculty of Medicine, 1,446.

${ }^{175}$ Steele, op. cit., note 165 above, p. 59; J Stark, 'Inquiry into the probable cause of the continued prevalence and fatality of small-pox', Edinburgh med. J., 1845, 64: 130-56, p. 133; Creighton, op. cit., note 33, pp. 600, 624; R S Orr, 'Statistics of the Royal Infirmary of Glasgow. Third Series.
}

Compiled from the records of the Institution for 1846', Edinburgh med. J., 1847, 67: 384-419, p. 419; Review: William Pulteney Alison,

'Observations on the management of the poor in Scotland, and its effects on the health of the great towns', Edinburgh med. J., 1840, 53: 494-509, pp. 496-7. The Mortality Bills were first published in 1821. Creighton, op. cit., note 33 above, vol. 2, p. 598.

${ }^{176}$ Steele, op. cit., note 165 above, p. 59; Stark, op. cit., note 175 above, p. 133; J McGhie, 'Remarks on the medical statistics of the Glasgow Royal Infirmary for 1853', Glasgow med. J., 1855, 2: $154-68$, p. 163. 
successfully implemented as it might. ${ }^{177}$ After all, the medical profession had promoted vaccination in Glasgow for over half a century-"It is therefore somewhat lamentable to reflect, that the first two years in the last half of the nineteenth century should conjointly exhibit a larger mortality from small-pox, than any similar period of which we have a record since the introduction of vaccination". Instead of blaming the profession, Steele identified several social factors for the continued prevalence of smallpox: first, "unjustifiable carelessness on the part of the poor", second, "a neglect of vaccination" between 1832 and 1852, which was, third, particularly noticeable among the children of the Irish poor. ${ }^{178}$ Fourth, there was sufficient evidence to show a considerable number of "post vaccine cases" in those past puberty, a category which had been increasing for some years. 179

It is clear from other sources that "Irish" was often used as a blanket term for "the low and labouring Highlanders and Irish" alike, ${ }^{180}$ but overall, the Irish were better vaccinated. ${ }^{181}$ Dr Robert Perry, ${ }^{182}$ writing of the smallpox epidemic of 1835 , stated that it "commenced \& was more general among female servants, and young men from the Highlands, \& western Islands of Scotland, than any other Class - their Clannish Intercourse greately favouring the spread of the contagion". ${ }^{183}$ Steele also observed "with what tenacity it clings to the Scotch branch in preference to the Irish". The predominance of Highlanders seems to have been less because of the poor's aversion to vaccination than, as the minister of the Isles of Coll and Tiree stated, the lack of a medical practitioner to perform it. ${ }^{184}$ Furthermore, there were problems with lymph deteriorating in the transmission to outlying areas. ${ }^{185}$ However, in $1852,45.5$ per cent of all smallpox deaths in Glasgow and its suburbs occurred in the Roman Catholic community (when

${ }^{177}$ Steele, op. cit., note 165 above, p. 59; Brunton, op. cit., note 28 above, p. 193 . Of the 163 patients admitted to the Royal Infirmary as a result of the epidemic in 1851, 30 died. Steele was clearly concerned at this high mortality which was blamed in the annual report on a neglect of vaccination among the Highland population. Jenkinson, et al., op. cit., note 39 above, p. 61 .

${ }^{178}$ Steele, op. cit., note 165 above, p. 61. Irish immigrants in other cities also exhibited a similar phenomenon. See, for example, Frances Finnegan, Poverty and prejudice: a study of Irish immigrants in York 1840-1875, Cork University Press, 1982, pp. 16-19.

${ }^{179}$ Steele, op. cit., note 165 above, pp. $63-4$; 'Medical Intelligence', Glasgow med. J., 1855, 3: 117; McGhie, op. cit., note 176 above, p. 164. In an analysis of 57 Glaswegians who took smallpox in 1852 after primary vaccination, the majority were affected between the ages of 15 and 25 . Steele, ibid., p. 69.

180 'Medical intelligence: small-pox', Glasgow med. J., 3rd series, 1855, 3: 116-17, p. 117.

${ }^{181}$ Orr, op. cit., note 175 above, p. 417 .

182 A native of Kilmarnock, Perry entered the
Faculty in 1812 . He was one of the early members of the Glasgow Medical Society, and went on to become Faculty President between 1843-45. He was physician to the Royal Infirmary for more than thirty years and physician to the Fever Hospital in Clyde Street. He had a particular interest in the treatment of fever. Duncan, op. cit., note 38 above, p. 272. As early as 1815 , he taught a course of public lectures, half of which was on preventive medicine. GUL Stack BG34-i-8, No. 7, 'Prospectus of a course of popular lectures on the animal economy, to be delivered by Dr. Perry, in his lecture room, Hutcheson's Hospital, Glasgow, 1815, Glasgow', Glasgow, s.n., 1815, pp. 11-12. Perry was the author of Facts and observations on the sanitory state of Glasgow, Glasgow, s.n., 1844.

183 RCPSG 2/1/24, Essays read before the Glasgow Medical Society, vol. 22, session 1834-35, No. 8, Robert Perry, M.D., 'On contagion, particularly the typhus contagion', pp. 31-2, 7 April 1835.

${ }^{184}$ Steele, op. cit., note 165 above, pp. 67-8.

185 William Reid, $A$ popular treatise on vaccination, Glasgow, David Robertson, 1840, p. 34. 


\section{Fiona A Macdonald}

approximately 30 per cent of the population of Glasgow was Roman Catholic), ${ }^{186}$ in spite of the endorsement of vaccination by the Catholic Bishop Murdoch in $1840 .^{187}$ Most of these were Irish. ${ }^{188}$

While the failure to contain smallpox was exacerbated by insufficient and inefficient vaccination, it had as much to do with the underdevelopment and lack of coordination in public health administration at this time. In the absence of a municipal isolation hospital until 1865, smallpox patients were accommodated in the Royal Infirmary, where the wards of the Fever-House shared the facilities of the general hospital, and in the outmoded Town's Hospital Infirmary. ${ }^{189}$ Furthermore, notification of infectious disease was inadequate, and in 1863, was still the responsibility of a non-medical inspector from the police force. ${ }^{190}$ Hardly surprising then, that at the introduction of monthly mortality returns in August 1855, the registrar bemoaned: "it is not creditable to our sanitary arrangements that small-pox should be allowed to continue its ravages unchecked by vaccination, as it appears to be in Dundee and Greenock". By September, the mortality from smallpox in nearby Greenock, the sixth largest town in Scotland, with an estimated population of 37,820 , had risen to 7.9 per cent and was "somewhat on the increase in Glasgow". ${ }^{191}$ At its most severe in Glasgow between April and October 1857, the new epidemic caused 58 deaths in June and constituted 6.7 per cent of fatalities there. In October, Glasgow and Paisley were jointly responsible for the entire smallpox mortality in Scotland. ${ }^{192}$ This situation again prompted the Faculty to consider remedial measures to revive vaccination in Glasgow, ${ }^{193}$ but stronger measures proved necessary in the long term. Dr James McGhie, Superintendent at the Royal Infirmary wrote, in 1855, that the medical profession in Glasgow afforded the fullest opportunity to everyone to be vaccinated gratuitously, but "though the penalty is either the death or disfigurement of their children, there are many who are so obtuse, ignorant, and careless, that nothing will move them but the strong arm of the law". 194

\footnotetext{
${ }^{186}$ Census of Great Britain, 1851. Religious worship, and education. Scotland. Report and tables, London, s.n., 1854, p. 339. Figure for Roman Catholic sittings in the Parliamentary City of Glasgow.

${ }^{187}$ McGhie, op. cit., note 176 above, p. 167; Reid, op. cit., note 185 above, p. $21 \mathrm{fn}$.

${ }^{188}$ In 1851 , only 5 per cent of the population of Glasgow were born in the Highlands and most came from the southern area bordering the Lowlands which was predominantly presbyterian. Devine, 'Urbanisation', op. cit., note 97 above, p. 42.

${ }^{189}$ Russell, op. cit., note 8 above, p. 329 ; Jenkinson, et al., op. cit., note 39 above, p. 50. The wards opened off a common stair where movement of medical attendants, nurses and of administrative staff with the general hospital was unrestricted, and they used the common washing-house, laundry,
}

mortuary, kitchen and dispensary. Russell, ibid., p. 329.

${ }^{190}$ Russell, ibid., p. 28.

191 'Death-Registration-small-poxvaccination', Glasgow med. J., 3rd s., 1860, 7: 443-57, pp. 445, 455.

192 Ibid., pp. 449-50.

193 RCPSG 1/1/1/8, 1858, pp. 551, 564-5.

${ }^{194}$ McGhie, op. cit., note 176 above, p. 164 . The statistician John Strang also agreed, in 1857, that it was not because of any deficiency on the part of the medical profession in Glasgow, "where perhaps the cow-pox innoculation was from the first greedily adopted by the surgeons who practised at the close of last century". John Strang, Report on the vital and economic statistics of Glasgow, for 1857, Glasgow, J MacNab, 1858, p. 10. 


\section{Legislation}

In England, measures had been taken which led to vaccination against smallpox becoming the first aspect of preventive medicine to be enforced by legislation. ${ }^{195}$ Under the English Vaccination Act of 1840 inoculation was finally declared illegal. ${ }^{196}$ At this time, there were still some 2,000 cases of smallpox annually in Glasgow and its suburbs. ${ }^{197}$ The English legislation seems to have encouraged the FPSG to put its own house in order, and on 1 August 1842, it appointed Mr Nathaniel Jones as second or Assistant Vaccinator. ${ }^{198}$ The Faculty marked the passing of the Compulsory Vaccination Act of 1853 in England by laying down specifications, on 7 March, for refurbishment of its vaccination room. ${ }^{199}$ It also began to get involved with the procedure outside its own area. Invited by Dr Cormack, Chairman of the Vaccination Committee of the Metropolitan Branch of the Medical and Surgical Association, London, the Faculty nominated three of its fellows, on 3 April 1854, to form part of the Joint Vaccination Committee. ${ }^{200}$

Calls for legislative intervention for compulsory vaccination in Scotland burgeoned in the late 1850s. Dr Pagan ${ }^{201}$ brought vaccination to the attention of the directors of Glasgow Royal Infirmary during the epidemic of 1857, in an attempt to induce them "to memorialize the Lord Advocate on the subject, and urge the necessity of legislative interference". ${ }^{202}$ In the same year, the Board of Supervision sanctioned vaccination by parish medical officers for those who were not objects of parochial relief, leading the medical profession "to inquire by what authority the Board of Supervision presumes to interfere with this matter at all". ${ }^{203}$ The FPSG also decided to petition Parliament to extend the provisions of the Vaccination Act to Scotland in January $1860 .{ }^{204}$ Under the English and Welsh Acts, vaccination practice had been placed firmly under the control of Poor Law officers despite a protracted struggle by medical practitioners to maintain some control over the practical aspects of technique. The Scots wished to avoid the former. Building on this experience, when vaccination legislation was drawn up for Scotland, the Scottish medical corporations including the FPSG, lobbied for, and achieved, significant amendments before it was passed, though the Bill was clearly modelled on the English

\footnotetext{
195 Brunton, op. cit., note 28 above, p. 193.

${ }^{196}$ David Van Zwanenberg, 'The Suttons and the business of inoculation', Med. Hist., 1978, 22: 71-82, p. 71.

${ }^{197}$ Reid, op. cit., note 185 above, p. v.

198 RCPSG $1 / 1 / 1 / 7$, p. 390 . Nathaniel Jones had served his apprenticeship with John Nimmo (probably William Nimmo's son) 1821-24. He was admitted as a licentiate on 2 May 1825 and when appointed vaccinator was concurrently assistant to John Pagan, Professor of Midwifery at Glasgow University, as well as Assistant Librarian to the FPSG. GUL Spec. Colls., Eph. K/124, Testimonials in favour of Mr. Nathaniel Jones, Assistant Librarian to the FPSG, and Licentiate of that body; RCPSG 1/1/1/6, p. 194; Duncan, op. cit., note 38 above, p. 263.
}

\footnotetext{
${ }^{199}$ RCPSG $1 / 1 / 1 / 8$, pp. 289-90.

${ }^{200}$ RCPSG $1 / 1 / 1 / 8$, p. 341.

201 John Pagan entered the Faculty in 1827 and was appointed a surgeon at the Royal Infirmary in 1833. He taught Medical Jurisprudence in Portland Street Medical School until 1840 when he was appointed to the Chair of Midwifery at Glasgow University. Duncan, op. cit., note 38 above, p. 283.

202 'Death-Registration', op. cit., note 191 above, p. 456; The Greater Glasgow Health Board Archive (hereafter GGHB) HB14/1/11, Glasgow Royal Infirmary Records, 1853 to 1858, p. 286.

203 J M Strachan, 'National vaccination provided by the Board of Supervision', Edinburgh med. J., 1857, 2: pt 2, 1133-35, p. 1134.

${ }^{204}$ RCPSG $1 / 1 / 1 / 9$, p. 87.
} 


\section{Fiona A Macdonald}

one. They particularly objected to the appointment of specialist vaccinators who drew income and control away from private practitioners in preference to the state. ${ }^{205}$ A degree of rivalry, over location, emerged between Glasgow and Edinburgh "when it became apparent that the chief object sought by some parties was the establishment of a vaccine institution in Edinburgh, on the London model with a staff of salaried officials". 206

The FPSG Council set up a committee, in January 1861, "to make inquiries and report upon the most likely mode of promoting and extending the practise of vaccination among the people". 207 By August, Council had full power to apply to the Privy Council for the appointment of a Public Vaccinator from among their number, proposing Drs Henry $\mathbf{R}$ Howatt ${ }^{208}$ and James Dunlop ${ }^{209}$ for the job. This looks like an attempt to pre-empt the anticipated outcome of Scottish legislation, and to secure the pre-eminence of the FPSG as the body which established the first vaccine institution in the west of Scotland. The appointment was eventually conferred on Dr Dunlop on 28 October. The Royal Infirmary (which had instituted free vaccination in 1857$)^{210}$ were considering a similar application, but this was seen to be in conflict with the Faculty, who "deprecate the appointment to a Professional Office of any Gentleman whose time is not devoted to the discharge of Professional duties".211 Clearly wishing to retain their influence as vaccination disappeared into the realms of central control, the FPSG Council recommended that Dr Dunlop publish the Privy Council requirements on certificates of competency to medical students, and his intention to lecture on the subject. They also granted him use of an apartment in Faculty Hall for the purpose. ${ }^{212}$ However, by June 1862, Council had decided that "they ought to exercise some control over his tenure of office and he should consent to demit his public appointment should the Faculty see fit to discontinue him as their own Vaccinator". 213 The Faculty appreciated the need for legislation, and the benefits they would incur from local government funding, but retained a vested corporate and professional interest in regulating the process in Glasgow.

\footnotetext{
${ }^{205}$ Brunton, op. cit., note 28 above, pp. 193 , $196-7$.

206 'Death-Registration', op. cit., note 191 above, p. 456; Alexander Wood, 'Small-pox in Scotland, as it was, and ought to be; with hints for its mitigation by legislative enactment', Edinburgh med. J., 1860 , 5: pt 2, 709-24, pp. 721-2.

${ }^{207}$ RCPSG $1 / 1 / 1 / 9$, p. 144 . Unfortunately the first extant Council Minutes Book, RCPSG 1/1/34, covers the period from 7 October 1862 to 29 September 1874 , so this reference to vaccination cannot be traced through.

${ }^{208}$ Henry Robertson Howatt became a licentiate of the FPSG in 1840. He graduated MD from Marischal College, Aberdeen, in 1851, and entered as Fellow of the Faculty on 4 August 1851. Medical directory, London, John Churchill, 1862, p. 738; RCPSG 1/1/1/8, p. 231.

209 James Dunlop graduated MD from Glasgow in 1857 . In the following year he became a licentiate
}

of the FPSG and entered as a resident Surgical Fellow of the Faculty on 4 June 1860 . He was a surgeon at the Royal Infirmary between 1874 and 1892. Medical directory, 1862, p. 730; RCPSG 1/1/1/9, p. 99; Jenkinson, et al., op. cit., note 39 above, p. 281.

210 'Death-registration', op. cit., note 191 above, p. 456. This was at the instance of Dr Pagan because of the smallpox epidemic in that year.

${ }^{211}$ RCPSG $1 / 1 / 1 / 9$, pp. 150,162 . It is not easy to clarify the nature of their concern here. However, there may be a clue in a motion carried on 21 June 1864 , that it be incumbent only on such of the Assistants as were registered practitioners to vaccinate children gratuitously. GGHB HB14/1/12, Glasgow Royal Infirmary Records, 1858 to 1864 , p. 348.

${ }^{212}$ RCPSG 1/1/1/9, p. 177.

${ }^{213}$ RCPSG $1 / 1 / 1 / 9$, p. 184. 


\section{Vaccination Policy of the FPSG}

Council petitioned Parliament for a second time in July 1863:

That the provisions of the said Vaccination Bill place the working of the Bill in the hands of the Board of Supervision and the Parochial authorities and are in this respect in the opinion of the Council of Faculty wrong in principle, complicated in their details and operations, and certain if carried into effect to prove injurious to the Medical Profession and the public.

It also complained that the Vaccination Bill did not provide for a supply of lymph to the medical profession or for the instruction of medical students in vaccination, and would, if passed, "destroy the vaccine Institution maintained by the Faculty with much extended usefulness for the last sixty two years".214 In their July amendments to the Bill (which the Scotsman inaccurately attributed entirely to the FPSG), the Lords ultimately agreed that parish medical officers would not have the title "Public Vaccinator", and would only vaccinate defaulters and the poor, so vaccination was not entirely to be placed in the hands of the Scottish Poor Law authorities, the parochial boards. ${ }^{215}$ With the passing of an Act to extend and make compulsory the practice of vaccination in Scotland, on 28 July $1863,{ }^{216}$ the medical profession won a qualified victory. Their final achievement, in 1867 , was the establishment, under the direction of Dr William Husband, of the Scottish Vaccine Institute in Edinburgh which had been sought by all the Scottish Colleges to coordinate lymph supplies. ${ }^{217}$

\section{Conclusion}

By 1805 , deaths from smallpox in Glasgow had fallen to 56, and in the period 1801 to 1812 the percentage mortality from smallpox in the under-tens-the group targeted by the Faculty's vaccination programme-was only 6 per cent. ${ }^{218}$ This compares favourably with the 19 per cent mortality in the same age group in the pre-vaccination period 1783 to $1800 .^{219}$ Flinn isolates this trend by analysing Watt's figures in six year periods which shows that the smallpox mortality in all deaths under ten was 8.9 per cent between 1801 and 1806 and fell to 3.9 per cent between 1807 and $1812 .^{220}$

The number of vaccinations performed by the FPSG during this period have been recounted for this paper. ${ }^{221}$ They include all vaccinations achieved at Faculty Hall, mostly

${ }^{214}$ RCPSG $1 / 1 / 1 / 9$, pp. $230-1$.

215 Brunton, op. cit., note 28 above, p. 199; D C Brunton, 'An alternative route: the Scottish Vaccination Act of 1863', unpublished typescript, 1996.

${ }^{216}$ The statutes of the United Kingdom of Great Britain and Ireland, vol. XXVI, Pt. 1, 1863, Cap CVIII. It became operational on 1 January 1864 .

${ }^{217}$ Brunton, op. cit., note 215 above, pp. 30, 34, $39-40$.

218 Watt, op. cit., note 58 above, pp. 361-72.

219 Ibid., pp. 343-60.

${ }^{220}$ Flinn (ed.), op. cit., note 29 above, p. 391.

221 There have been at least two previous attempts (probably nineteenth century) to count the

\author{
vaccinations in the Faculty's registers, but spot- \\ checking proved both to be inaccurate. Pencil \\ figures appear in some of the earliest registers at the \\ top and the foot of the page and were probably an \\ attempt to calculate returns for the official \\ submissions to the NVE. Though each vaccinee was \\ given a sequential number, due to scribal and \\ sequential errors, the running total was soon \\ inaccurate. See, for instance, the third register, \\ where the numbering sequence jumps from No. 1102 \\ on p. 31 to No. 3103 at the top of p. 33 . Pencil \\ calculations in Register eleven run only to August \\ 1840 where there is a pencil note: "Vaccinations \\ from 15 May 1801 to 17 th August 1840 Inclusive \\ 31,374 ". RCPSG $1 / 7 / 11$, p. 138.
}


(a)

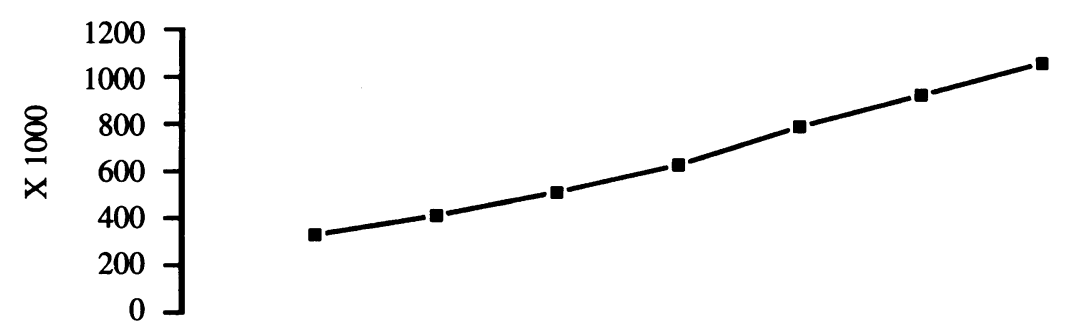

(b)

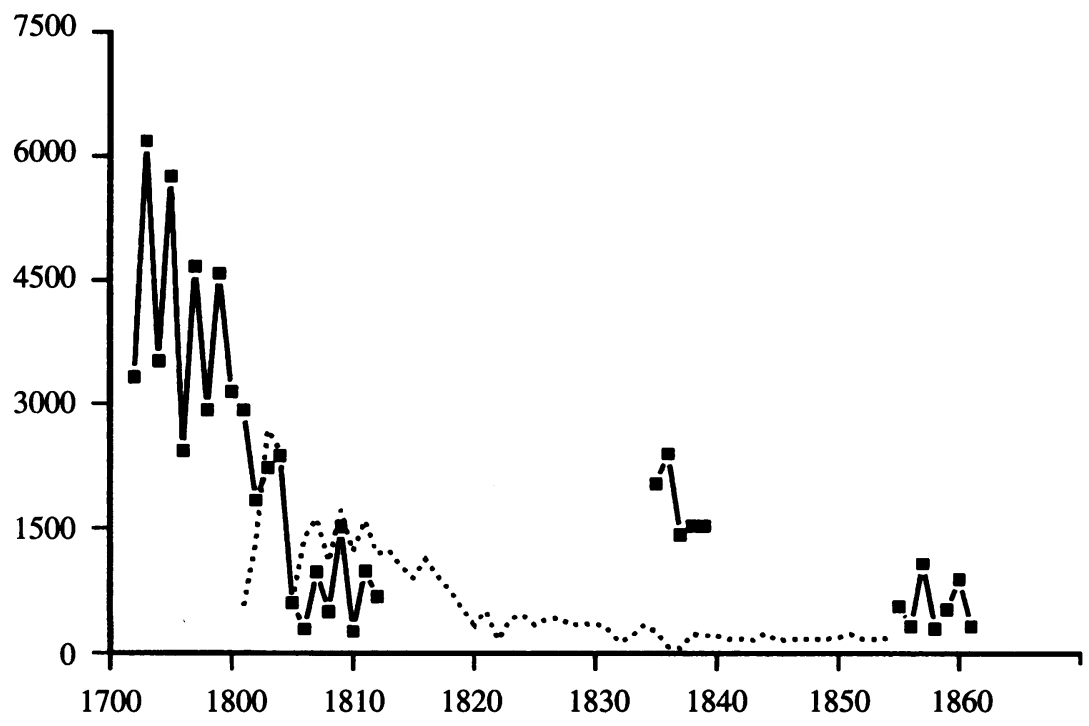

Figure 3: (a) Population of the western Lowlands.

(Source: M W Flinn (ed.), Scottish population history, Cambridge University Press, 1977, Table 5.1.3, p. 306.)

(b) ...... Number of FPSG vaccinations (per annum) compared with $\bullet$ death rate (per million in Glasgow from smallpox.

(Sources: RCPSG 1/7/1-11; A Newsholme, 'The epidemiology of small-pox in the nineteenth century', Br. med. J., 1902, ii: 17-26, p. 19.)

free vaccination of the poor, but also a small number of private vaccinations. ${ }^{222}$

A comparison of Faculty vaccinations with smallpox mortality (Figure 3b) shows, in common with trends in many industrial towns in Britain and as intimated by McKeown, that smallpox mortality in Glasgow was declining prior to the advent of vaccination. Immediately after the introduction of vaccination to Glasgow, most apparent is the clear relationship between peaks in smallpox mortality and peaks in the vaccinations

222 Official figures for FPSG vaccinations, given in various publications by the statistician Cleland, were for vaccinations performed free of charge only. For these see Cleland 1816, op. cit., note 131 above, vol. 1 , p. 213; idem, 1820, op. cit., note 155 above, p. 198; idem, 1832, op. cit., note 174 above, pp. 21-2. 
achieved. $^{223}$ This indicates that preventive measures had not yet brought smallpox outbreaks under control, and that people raced to Faculty Hall whenever smallpox was in the vicinity. After achieving an average of 1,575 vaccinations per annum ${ }^{224}$ in the first decade, the numbers vaccinated in the second decade dropped to around 930 per annum, ${ }^{225}$ apparently because there was very little smallpox in Glasgow at that time. Unfortunately, there are no registered mortality statistics between 1812 and 1835 to prove this point, but according to Cleland, there were only 236 deaths from smallpox in Glasgow between 1813 and 1819 , a mere 1.07 per cent of the mortality rate. Since there are no accurate data for births prior to civil registration in Scotland in 1855, there can be no reliable figure for the percentage of the infant population reached by vaccination, but Creighton estimated that no more than a quarter of children in Glasgow were vaccinated between 1812 and 1818.226 A comparison of Faculty vaccinations with the rising population of the west Lowlands of Scotland (Figure 3a), indicates that even before the opening of the Cowpock Institution in 1818, the FPSG's vaccination campaign was failing to keep pace with population growth.

After the initial success of the Faculty's programme, there was a sharp decline in vaccinations in the $1820 \mathrm{~s}$. What were the important factors in this? Most important, the fear engendered by smallpox declined, mainly as a result of the fairly rapid decrease in smallpox mortality in the first decade of the nineteenth century, which continued into the second. When neither surgeons nor members of the public were yet generally aware of the necessity for revaccination, this led to a degree of apathy where vaccination was often performed only when an epidemic threatened. Decline in attendance at Faculty Hall in the 1820 s caused a major reappraisal of their vaccination policy. The decline in attendance further resulted in shortages of lymph. 227

With the general increase in population, and the epidemic nature of smallpox, this inattention to immunization led to a marginal increase in smallpox deaths in Glasgow in the late 1830s and 1840s. Dr Robert Cowan blamed the increase on "the neglect of vaccination, and not the occurrence of small-pox after vaccination". ${ }^{228}$ The 2,196 deaths from smallpox between 1835 and 1839 accounted for 5.4 per cent of the total mortality. ${ }^{229}$ Of these, 1,933 were children under five,${ }^{230}$ indicating that the majority of those who died from smallpox after the introduction of vaccination were still children. Most adults were protected either by vaccination or by a bout of the disease. The only exception to this high childhood mortality was in the group of emigrants from the Highlands and Ireland, who had acquired less immunity to the disease in rural areas and had a much higher mortality from smallpox as adults than city-dwellers. More significant was Steele's conclusion that vaccination had not been implemented as successfully as it might. ${ }^{231}$ In praising the efforts of the medical profession thus far, he was clearly stressing the need for enforced

\footnotetext{
${ }^{223}$ A similar association was noted by Mercer in the pre-vaccination period in Whitehaven. Disease, mortality and population, op. cit., note 22 above, pp. $65,67$.

22418 May 1801 to 29 July 1811 -rounded up from 1,574. RCPSG $1 / 7 / 1-6$.

22529 July 1811 to 31 December 1821 . RCPSG 1/7/7-9.
}

\footnotetext{
${ }^{226}$ Creighton, op. cit., note 33 , vol. 2, pp. 582-3.

${ }^{227}$ Flinn (ed.), op. cit., note 29 above, p. 394.

${ }^{228}$ Review: Robert Cowan, 'Vital statistics of

Glasgow', Edinburgh med. J., 1893, 51: 542.

${ }^{229}$ Flinn (ed.), op. cit., note 29 above, pp. 394-5.

${ }^{230}$ Reid, op. cit., note 185 above, pp. 19-20;

Creighton, op. cit., note 33, vol. 2, p. 571.

${ }^{231}$ Steele, op. cit., note 165 above, p. 59.
} 


\section{Fiona A Macdonald}

public health measures and legislation to support them. When the mortality from smallpox in Greenock, just down the Clyde, reached 7.9 per cent in 1855 and 6.7 per cent in Glasgow in the summer of 1857 , the Faculty also realized that the only way of significantly increasing numbers presenting for vaccination in the city was to join the lobby for a Scottish Compulsory Vaccination Act.

What can be ultimately concluded from this study of voluntary public vaccination by the FPSG between 1801 and 1863? Certainly, smallpox mortality in Glasgow never returned to eighteenth-century levels. ${ }^{232}$ The reason for this lies in a combination of factors outlined in the main theses of both McKeown and the revisionists. Though there were periods of severe economic hardship in the early nineteenth century-for example in 1834 when it has been estimated that half of all Scottish weavers existed below the poverty line $\mathrm{e}^{233}$ — the diet of the urban poor in Glasgow probably marginally improved. ${ }^{234}$ However, a clearly established, downward trend in smallpox mortality can be traced from the late eighteenth century. Anne Hardy argues that this was due to a reduction in smallpox virulency in the first half of the nineteenth century, ${ }^{235}$ but if the fatality of the disease was partly mitigated by widespread inoculation, ${ }^{236}$ the west of Scotland contributed little to this. According to Sir John Sinclair's Old statistical account inoculation was "yet far from being generally practised" in Glasgow in the 1790s, ${ }^{237}$ when most popular. ${ }^{238}$ A downward trend notwithstanding, smallpox mortality still declined markedly between 1805 and 1812, and vaccination at Faculty Hall played a large part in this. However, Glasgow doctors showed no apparent appreciation of the advent of a more fatal form of the disease in the late 1850 s but chose, instead, to blame the high smallpox mortality on the Highlanders who were "the means of propagating it among the families, and in the houses and factories in which they are employed". 239

On the other hand, the period of voluntary vaccination in Glasgow cannot be held up as entirely successful because smallpox continued in the top six of childhood killers, though it now occupied sixth rather than first position. ${ }^{240}$ There was also a variety of problems (of conscience and technique) ${ }^{241}$ with the voluntary implementation of this interventionist

\footnotetext{
$232 \mathrm{M}$ W Flinn, The European demographic system 1500-1820, Brighton, Harvester, 1981, p. 99;

Chalmers, op. cit., note 5 above, pp. 351-2. For a

graph of the mortality rate in Glasgow from

smallpox per million inhabitants, 1787-1812,

1835-39 and 1855-1900, see A Newsholme, 'The

epidemiology of small-pox in the nineteenth century', Br. med. J., 1902, ii: 17-26, p. 19.

${ }^{233} \mathrm{R}$ A Cage, 'Health in Glasgow', in idem, The working class in Glasgow 1750-1914, London, Croom Helm, 1987, pp. 56-76, p. 66.

234 Treble, op. cit., note 166 above, p. 205; I Levitt and C Smout, The state of the Scottish working class in 1843: a statistical and spatial enquiry based on the data from the Poor Law Commission Report of 1844, Edinburgh, Scottish Academic Press, 1979, pp. 29-30.

${ }^{235}$ Hardy, The epidemic streets, op. cit., note 24 above, p. 114.

${ }^{236}$ Hardy, 'Smallpox in London', op. cit., note 24 above, p. 113.

${ }^{237} \mathrm{D} J$ Withrington and I R Grant (eds), The
}

statistical account of Scotland, Lanarkshire and Renfrewshire, Wakefield, EP Publishing, 1973, vol. 7, p. 339.

${ }^{238}$ Brunton, op. cit., note 27 above, p. 406.

239 Jenkinson, et al., op. cit., note 39 above, p. 61 , quoting Annual Report of 1859.

${ }^{240}$ Flinn (ed.), op. cit., note 29 above, Table 5.6.1, p. 389; W F Bynum, Science and the practice of medicine in the nineteenth century, Cambridge University Press, 1995, p. 85.

${ }^{241}$ For the English debate see A Beck, 'Issues in the anti-vaccination movement in England', Med. Hist., 1960, 4: 310-21; R M MacLeod, 'Law, medicine and public opinion: the resistance to compulsory health legislation 1870-1907', Public Law, 1967, pt 1, 107-28; pt 2, 189-211; D Porter and $\mathrm{R}$ Porter, 'The politics of prevention: antivaccinationism and public health in nineteenthcentury England', Med. Hist., 1988, 32: 231-52. The latter also includes some later material relevant to the Glasgow context, pp. 234, 237-8, 240-3, 245. 


\section{Vaccination Policy of the FPSG}

medical procedure. Though the Faculty tried to limit technical failures in a number of ways - for example by curtailing the involvement of untrained apprentices in lymph withdrawal-contaminated lymph could cause secondary infections. Furthermore, while the Faculty supplied lymph to their licentiates in rural areas, there is little to indicate that the introduction of vaccination into the rest of its extensive boundaries was in any way pursued systematically. In the city, the Faculty's inability to sustain attendance during the third decade of the century and thus maintain the decline in smallpox mortality, supports Szreter's argument for the necessity of local sanitary adminstration and public health legislation in effecting such a change. This was not to happen until the 1870 s.

The Faculty should be recognized, none the less, for its willingness to introduce the only specific prophylactic measure which existed against disease during this period. ${ }^{242}$ Vaccination was the main feature of preventive policy against smallpox from 1801 to the $1860 \mathrm{~s},{ }^{243}$ and the Faculty was entirely responsible for its introduction into Glasgow. It was due to the Faculty's example that gratuitous vaccination was subsequently taken up by other bodies in the city. By 1857, six stations in Glasgow ${ }^{244}$ - the FPSG, the Medical Association in St Andrew's Square, ${ }^{245}$ the University Lying-in Hospital, the Lying-in Hospital in St Andrew's Square, the Eye Infirmary, and the Glasgow Royal Infirmarywere vaccinating free of charge. The Royal Infirmary supplied lymph further afield than the FPSG, not only to the Highlands of Scotland but sometimes "to distant parts of the world" such as South America and Syria. ${ }^{246}$ Though the Faculty had long ceased to be the major station for vaccination, the public vaccination campaign which started as a local initiative eventually had an international outreach. There were undeniable problems with the implementation of arm-to-arm vaccination during this period, but it is surely within the context of a desire to diminish human suffering that the Faculty's vaccination policy between 1801 and 1863 should primarily be seen. It was not simply their promotion of the procedure but the furnishing of facilities and means to implement vaccination on a substantial scale, particularly in the first two decades of the century, which resulted in a positive effect on smallpox mortality in Glasgow.

\footnotetext{
${ }^{242}$ Bynum, op. cit., note 240 above, p. 84.

${ }^{243}$ Hardy, The epidemic streets, op. cit., note 24 above, pp. 149-50.

${ }^{244}$ This met with the criterion established by Mr Robert Ceely of Aylesbury, in his 1853 recommendations to the Secretary of State, who said that a station offering careful vaccination, on a weekly basis, and maintained by its own operation, could not function in a population of less than 60,000 . The President of the Royal College of Physicians in Edinburgh also declared in 1860 that "Glasgow, with an estimated population of 388,537,
}

and 5,887 births annually, would require six stations". Wood, op. cit., note 206 above, p. 722; Review: 'Exposition of a method of preserving vaccine lymph, fluid and active, etc. By William Husband', Edinburgh med. J., 1860, 5, pt. 2, 949-51, p. 950 .

245 That is, the Wee Faculty.

${ }^{246}$ Smith, op. cit., note 88 above, p. 163; 'Medical intelligence: quarterly report of the state of disease in the Glasgow Royal Infirmary, for the quarter ending the 30th September, 1858', Glasgow med. J., 3rd s., 1858-59, 6: $380-3$, p. 381 . 